\title{
Crustal structure variations along the NW-African continental margin: a comparison of new and existing models from wide-angle and reflection seismic data
}

\author{
Klingelhoefer Frauke ${ }^{1}$, Biari Youssef ${ }^{1,2,4}$, Sahabi Mohamed ${ }^{2}$, Aslanian Daniel ${ }^{1}$, Schnabel Michael ${ }^{3}$, \\ Matias Luis ${ }^{4}$, Benabdellouahed Massinissa ${ }^{5}$, Funck Thomas ${ }^{6}$, Gutscher Marc-André ${ }^{4}$, \\ Reichert Christian ${ }^{3}$, Austin James A. ${ }^{7}$
}

\footnotetext{
${ }^{1}$ Ifremer, Department of Marine Geosciences, ZI de la Pointe de Diable, 29280 Plouzané, FRANCE

${ }^{2}$ Université Chouaïb Doukkali - Faculté Des Sciences, Laboratoire Géosciences marines et Sciences des sols - URAC 45, BP 20, 24000 El Jadida, MAROC

${ }^{3}$ Bundesanstalt fuer Geowissenschaften und Rohstoffe, (BGR), Geozentrum Hannover, Stilleweg 2, 30655 Hannover, GERMANY

${ }^{4}$ Instituto Dom Luiz, Campo Grande, Ed. C6, piso 3, 1749-016 Lisboa, Lisboa, PORTUGAL

${ }^{5}$ Universite Européene de Bretagne, Brest/ Institut Universitaire Europeen de la Mer, UMR 6538

Domaines Oceaniques, Place Nicolas Copernic, F-29280, Plouzane, FRANCE

${ }^{6}$ GEUS - Geological Survey of Denmark and Greenland, Øster Voldgade 10, 1350, Copenhagen K, DENMARK

${ }^{7}$ The University of Texas at Austin, John A. and Katherine G. Jackson School of Geosciences, Institute for Geophysics, J.J. Pickle Research Campus, Bldg. 196, rm. 3.254, 10100 Burnet Road (R2200), Austin, Texas, UNITED STATES OF AMERICA
}

\begin{abstract}
:
Deep seismic data represent a key to understand the geometry and mechanism of continental rifting. The passive continental margin of NW-Africa is one of the oldest on earth, formed during the Upper Triassic-Lower Liassic rifting of the central Atlantic Ocean over $200 \mathrm{Ma}$. We present new and existing wide-angle and reflection seismic data from four study regions along the margin located in the south offshore DAKHLA, on the central continental margin offshore Safi, in the northern Moroccan salt basin, and in the Gulf of Cadiz.

The thickness of unthinned continental crust decreases from $36 \mathrm{~km}$ in the North to about $27 \mathrm{~km}$ in the South. Crustal thinning takes place over a region of $150 \mathrm{~km}$ in the north and only $70 \mathrm{~km}$ in the south. The North Moroccan Basin is underlain by highly thinned continental crust of only 6-8 km thickness. The ocean-continent transition zone shows a variable width between 40 and $70 \mathrm{~km}$ and is characterised by seismic velocities in between those of typical oceanic and thinned continental crust. The neighbouring oceanic crust is characterised by a thickness of 7-8 km along the complete margin. Relatively high velocities of up to $7.5 \mathrm{~km} / \mathrm{s}$ have been imaged between magnetic anomalies S1 and M25, and are probably related to changes in the spreading velocities at the time of the Kimmeridgian/Tithonian plate reorganisation.
\end{abstract}


Volcanic activity seems to be mostly confined to the region next to the Canary Islands, and is thus not related to the initial opening of the ocean, which was associated to only weak volcanism. Comparison with the conjugate margin off Nova Scotia shows comparable continental crustal structures, but 2-3 km thinner oceanic crust on the American side than on the African margin.

\section{Highlights}

- This compilation deep seismic data from the NW African margin reveals variations of the crustal thickness and structure along the margin. The continent-ocean transition zone is broader in the North and narrowing in the South - Continental crust thins from $37 \mathrm{~km}$ to only 28 from North to South Comparison to the conjugate NE American margin gives insight into early stages of continental breakup and accretion of early oceanic crust.

Keywords : Moroccan continental margin, wide-angle seismic, passive margins, deep structure, plate reconstruction 


\section{Introduction}

The Moroccan margin formed during initial rifting of the Atlantic is one of the oldest passive margins in the world. Its deep structure is still less well know than that of its conjugate, the Nova Scotian Margin (Funck et al., 2004 ; Keen and Potter, 1995a, Luheshi et al., 2012). During rifting three major salt basins were formed along the margin. After rifting and the onset of sea floor spreading, the convergence between the African and Eurasian plates leading to the buildup of the Atlas mountain system in Eocene times was recorded in the structure of the margin (Dewey et al., 1989, Rosenbaum et al., 2002). Volcanism due to the presence of the Canary and Cape Verde mantle plumes affected the margin inducing the buildup of numerous volcanic islands (Carracedo et al., 1998, Hoernle and Schmincke, 1993).

The NW African margin is a key to understand rifting of magma-poor margins. It allows studying the mechanisms of opening by mapping the extent of continental and oceanic domains and the presence of exhumed upper mantle or volcanic underplate in the ocean-continent transition zone. Consequently, the deep structure of this margin was subject to numerous geophysical and geological studies during the last 30 years (Hinz et al., 1982; LeRoy et al., 1997; Roeser, 1982; Contrucci et al., 2004; Klingelhoefer et al., 2009; Biari et al., 2015) (Figure 1). Lately hydrocarbon exploration activity increased along this margin, with exploration wells drilled on the shelf (Tari et al., 2012; Jabour et al., 2007). This activity also triggered interest in searching for analogue plays in the conjugate margin off Nova Scotia, Canada (Luheshi et al., 2012).

In this paper we will present and compare existing and new deep seismic data sets from the NW African margin (Figure 1) along with a review of existing work regarding magnetic anomalies constraining the opening of the Atlantic, plate kinematic reconstructions and proposed mechanisms of opening. A comparison with the conjugate margin will be presented in the last chapter.

\subsection{Opening of the central Atlantic ocean}

The Moroccan margin formed during initial rifting of the Atlantic in upper Trias or lower Lias times. Although today timing of the opening of the oceanic basin is well known from mapping of the magnetic anomalies, the pre-rifting phase is still mostly unknown (LeRoy, 1997 ; LeRoy et al., 1997).

\subsubsection{Magnetic anomalies identified along the margin}

In the central Atlantic between the Mid-Atlantic Ridge and Africa, about $1100 \mathrm{~km}$ of linear magnetic anomalies are observed of the Cenozoic/Upper Cretaceous sequence 1-34 (Cande and Kent, 1995). Bordering these is a $600 \mathrm{~km}$ wide region with only weak and irregular anomalies created during the Cretaceous magnetic quiet time. Farther towards the continents 300-km-wide strip with linear anomalies consists of the Mesozoic anomalies M0-M25 (Kent and Gradstein, 1986). Bordering these anomalies is a 400-km-wide zone of smooth magnetic anomalies, which was created during the Jurassic Magnetic Quiet Time (Heezen et al., 1953; Roeser, 1982).

A prominent magnetic anomaly called slope anomaly (S1) or West African Coast Magnetic Anomaly (WACMA) is situated near the continental slope at the western end of a province of salt diapirs and is thought to mark the ocean-continent transition at its oceanward side (Roeser, 1982) 
(Figure 2). This high amplitude magnetic anomaly can be traced along the west African margin. It represents the conjugate to the East Coast Magnetic Anomaly (ECMA) at the north American margin, which analogously is also proposed to mark the ocean-continent transition at its oceanward side (Hinz et al., 1982; Roeser, 1982; Roeser et al., 2002 ; Sahabi et al., 2004).

At the African margin, the anomaly has a lower amplitude but similar shape and is parallel to its north American conjugate (Sahabi et al., 2004, based on the map of: Verhoef et al., 1996). It can be traced from the northern Moroccan salt basin down to Senegal in the south. Only one segment at its northern tip to which no conjugate at the Canadian margin exists, the northern Moroccan salt basin (Roeser et al., 2002). In the south of the Moroccan margin the WACMA is situated closer to the continent than in the north and is characterised by a higher amplitude than in the north.

The conjugate East Coast Magnetic Anomaly (ECMA) is a strong and continuous magnetic anomaly, extending from Georgia to Nova Scotia, (Drake et al., 1959; Keller et al., 1954) varying in character along the margin. Off Nova Scotia, this anomaly weakens progressively to the north until its disappearance in the northeastern segment of the Nova-Scotia margin (Dehler, 2012; Funck et al., 2004). South of the Atlantis Fracture zone $\left(38^{\circ} \mathrm{N}\right)$ a magnetic anomaly called Blake Spur Magnetic Anomaly (BSMA) is located about $220 \mathrm{~km}$ oceanwards of the ECMA and is paralleling it (Vogt, 1973).

\subsubsection{Timing/Plate reconstructions}

Based on comparison of the shorelines and the fauna on the African and South American continents Alfred Wegener proposed, that these continents once formed a single landmass (Wegener, 1912). In later work in order to improve the simple shoreline fit of the North American and African continent the edge of the continent or "hinge line" was used (Bullard et al., 1965). Later reconstructions used seafloor magnetic anomalies and aspects of regional geology as well as intraplate deformation in order to improve the reconstructions of the north and central Atlantic (Pitman and Talwani, 1972; Olivet, 1978; Olivet 1984).

A comprehensive study of magnetic lineations and bathymetric patterns allowed determination of a set of finite-difference poles to describe the kinematic history of the opening of the central Atlantic (Klitgord and Schouten, 1986). A ridge jump at the Blake Spur Magnetic Anomaly (BSMA) originally proposed by Vogt (1973) and a major plate reorganisation of the spreading in late Bathonian time resulted in the creation of a new spreading system characterized by smaller $(<100 \mathrm{~km})$ transform offsets. An alternative explanation to the ridge jump is, that the WACMA anomaly represents the conjugate of the BSMA and the conjugate anomaly to the ECMA is found further inland on the Moroccan margin side (Roest et al., 1992).

The onset of sea floor spreading and the formation of the first oceanic crust remains uncertain and may have been as late as $175 \mathrm{Ma}$ (Klitgord and Schouten, 1986). However, a more recent study based on the correlation of magnetic anomalies, salt distribution and seismic data from both margins (Sahabi et al., 2004) proposed the oldest oceanic crust to be of Sinemurian times (195 Ma), $20 \mathrm{My}$ older than that of previously published work (Klitgord and Schouten, 1986).

On the basis of asymmetries of the magnetic anomalies at the Moroccan side Schettino and Turco 
(2009) propose a new reconstruction taking into account an independent movement of the Meseta block and the accommodation of the shortening due to the Atlas orogeny. Their fit includes a ridge jump at the time of the BSMA, which leaves part of the originally Moroccan oceanic plate at the Canadian side.

Instead of invoking a ridge jump the asymmetry between the width of the western part of the central Atlantic Ocean and the eastern part can be explained by asymmetric accretion of ocean crust from the start of rifting up to M22 anomaly (Labails et al., 2010). The authors propose the existence of an anomaly conjugate to the BSMA at the African margin. The proposed initial opening direction implies a significant oblique plate motion and a slower spreading rate than determined in previous studies.

\subsubsection{Process of opening and influence on the resulting deep structure}

One of the first models of initial opening of this margin is based on the interpretation of two wideangle seismic profiles offshore Morocco and Mauritania (Weigel et al., 1982). The authors propose that prior to the initial rifting leading to separation of the American and African continent an upwelling zone of mantle material extends several thousands of $\mathrm{km}$ in the direction of the rift. Seismic velocities between $7.1-7.3 \mathrm{~km} / \mathrm{s}$ detected on both profiles on a several hundredth of $\mathrm{km}$ wide region paralleling the coast are proposed to result from frozen former plume head (Weigel et al., 1982).

The comparison of wide-angle seismic models SMART 1 (Funck et al., 2004) from the Canadian and SISMAR 4 (Contrucci et al., 2004) from the African continental margin and especially the fact that the basin on the African margin is underlain by continental crust lead to the interpretation that break-up occurred along a lithospheric detachment fault, leaving a higher amount of upper crustal material at the African and lower crustal material on the Canadian margin (Maillard et al., 2006). The opening is proposed to be accompanied by minor volcanism on the African side and the exhumation of upper mantle material along its conjugate. The authors propose that the volcanic products were guided by the detachment fault and produced the S1 magnetic anomaly (Figure 3).

This interpretation was extended along the margin using industrial reflection seismic data (Tari and Molnar, 2005) (Figure 4). Based on kinematic reconstruction using syn-rift structures across the Central Atlantic identified in the seismic sections, the authors propose that the Moroccan margin is divided into an upper plate margin in the north and a lower plate margin in the south (Figure 4). The authors propose that the Tafelney accommodation zone separates the lower and upper plate segments (Tari and Molnar, 2005).

Remodelling of the SISMAR 4 wide-angle seismic profile using tomographic approaches and comparison to the existing OETR 2009 profile (Luheshi et al., 2012) located on the Canadian continental margin indicates that rifting took place in a more symmetric initial phase including a rift jump which separated a part of the Canadian thinned continental crust from the margin leaving it at the African margin at the location of the SISMAR 4 profile (Sibuet et al., 2012, Sibuet et al., 2010) (Figure 5). This phase ended with the exhumation of upper mantle material on both margin sides. It was followed by a major westward ridge jump at the time of creation of the ECMA anomaly, which 
as a consequence placed the complete region of serpentinised upper mantle zone on the Canadian margin (Sibuet et al., 2012; Sibuet et al., 2011).

\subsection{Segmentation of the NW-African Margin}

Different segmentation geometries for the Moroccan margin have been proposed taking into account the width of the shelf region, the distribution of salt diapirs, the rifting morpholgy, the characteristics of the magnetic anomalies ECMA and WACMA, the magmatic activity and the deep crustal structure. This chapter presents the segmentation of the Moroccan margin from previously published papers based on reflection lines (Hinz et al., 1982 - 5 segments) and on the amount of volcanic products (Louden et al., 2013 - 3 segments). It then proposes a new segmentation based the interpretation of magnetic anomalies and the distribution of salt basins along the margin.

Based on reflection seismic profiles along the continental margin from three oceanographic cruises five distinct segments were defined along the Moroccan margin from South to North: The North Tarfaya segment $\left(28^{\circ}-30^{\circ} \mathrm{N}\right)$ sloping smoothly seaward, the Tafelney Plateau $\left(30.0^{\circ}-31.5^{\circ} \mathrm{N}\right)$, a large marginal plateau of about $3500 \mathrm{~km}^{2}$, the Essaouira segment $\left(31.5^{\circ}-33.0^{\circ} \mathrm{N}\right)$, distinguished by an irregular seafloor relief, the Mazagan Plateau $\left(33.0^{\circ}-33.6^{\circ} \mathrm{N}\right)$ off the Morrocan Meseta and the Pre-Rif segment $\left(33.6^{\circ}-35.0^{\circ} \mathrm{N}\right)$, characterised by a larger continental slope than in the south (Hinz et al., 1982) (Figure 2B). This study did not extend further south than $28.0^{\circ} \mathrm{N}$.

Major along strike variations in rifting styles were proposed based on the SMART wide-angle seismic profiles, the SISMAR 4 profile and additional industrial reflection seismic profiles (Louden et al., 2013). The southernmost boundary located at the southern limit of the Moroccan Salt Basin represents a change from magma rich to magma poor opening (Figure 6). The second transition located at the Tafelney Plateau represents further reduction of volcanism, the creation of highly tectonised oceanic crust and the exhumation of upper mantle material. The authors propose that this transition marks a major change in rifting asymmetry and separates the margins into two fundamentally distinct segments.

In this work we distinguish four segments along the Atlantic continental margin based on analysis of the magnetic anomalies and the distribution of the salt basins along the margin. They correspond to the three segments defined in earlier work (Louden et al., 2013) with the addition of one segment in the Gulf of Cadiz. The southern segment between $20^{\circ}$ and $29^{\circ} \mathrm{N}$ (Figure $2 \mathrm{~B}$ ) in which the WACMA is strong and located close to the coastline. On the conjugate margin ECMA is strong and the BSMA is located seaward of the margin. In the central segment between $29^{\circ}$ and $35^{\circ} \mathrm{N}$, the BSMA cannot be identified on the conjugate Canadian margin. The northernmost segment is the North African salt basin. It is characterised by an increase in distance between the WACMA and the coastline. The last region of this study is the Gulf of Cadiz, originating from highly oblique rifting and seafloor spreading along the Africa-Eurasia plate boundary during an episode of oblique seafloor spreading and thus belonging to the western extremity of a Tethyan oceanic domain (Frizon de Lamotte et al., 2011; Sallares et al., 2011; Schettino and Turco, 2011; Stampfli and Borel, 2002; Stampfli et al., 2002) 


\section{Review on the crustal architecture}

\subsection{The southern segment $\left(20^{\circ}-29^{\circ} \mathrm{N}\right)$}

The first wide-angle seismic data along the NW-African margin were acquired onboard R/V Meteor (Goldflam et al., 1980; Weigel et al., 1982). Between the continental slope and the Canary Islands an up to $7 \mathrm{~km}$ thick sedimentary basin is imaged (Goldflam et al., 1980; Weigel et al., 1982). The underlying layer of $5.1 \mathrm{~km} / \mathrm{s}$ is interpreted to either consist of older sediments or represent an unusually smooth oceanic basement. A deeper refractor of 7.1-7.2 km/s is proposed to be cooled and contracted mantle material, which will gradually increase to normal mantle velocities thereby not producing a $8.00 \mathrm{~km} / \mathrm{s}$ arrival (Weigel et al., 1982) or alternatively as a high-grade metamorphic equivalent of the gabbroic oceanic layer 3. However, these velocities correspond to serpentinised mantle material, a fact unknown at that time. Based on this analysis the authors propose that the crust in this region is not typical oceanic crust even if the $5.1 \mathrm{~km} / \mathrm{s}$ layer might consist of pillow lavas (Weigel et al., 1982). Typical oceanic crust was imaged west of the M25 magnetic anomaly (Goldflam et al., 1980).

During the DAKHLA cruise four wide-angle and deep reflection seismic profiles were acquired on the southern Moroccan margin (Figures 7 and 8). Two profiles perpendicular to the margin were extended on land using seismic stations and Vibroseis signals. One of these profiles was designed to reach from unthinned continental crust across the first magnetic anomaly M25. In this region the WACMA is located close to the continent, indicating abrupt crustal thinning (Figure 8).

Modelling of the combined reflection and wide-angle seismic data allowed imaging the deep structure of the continental margin. Here, the unthinned continental crust has a thickness of $27 \mathrm{~km}$ thickness, and is composed of two layers 12 and $15 \mathrm{~km}$ thick (Figure 9) (Klingelhoefer et al., 2009). A $60-\mathrm{km}$-wide zone of crustal thinning and slightly elevated lower crustal velocities is imaged landward of the S1 magnetic anomaly. The origin of the elevated seismic velocities is proposed to result from intrusions into the lower crustal layer, as there is no double reflection which is observed for a separate underplate layer (Klingelhoefer et al., 2009). On top of the crust in this region is a shallow-water Jurassic-Early Cretaceous (Berriasian), carbonate platform (Labails and Olivet, 2009). Further oceanward a zone of crust of unknown composition beneath an up to $10 \mathrm{~km}$ thick sedimentary basin is modelled. Its basement is characterized by a blocky character. It is interpreted to be composed of a thin oceanic crust containing high amounts of serpentinite related to very slow spreading between 195 and 165 Ma. Labails and Olivet (2009) propose the existence of a magnetic anomaly conjugate to the BSMA in this region.

West of this zone, a region of oceanic-type crust displaying relatively high velocities in the lower crust $(7.00-7.40 \mathrm{~km} / \mathrm{s})$ as compared to normal Atlantic oceanic lower crustal velocities $(6.69 \pm 0.26$ White et al., 1992) is modelled. Here the crust is characterised by a smooth basement and a slightly higher than normal thickness. Large faults that cross-cutting the entire crust are imaged by the coincident reflection seismic data (Labails and Olivet, 2009). West of magnetic anomaly M25 the oceanic crust is characterised by rough basement typical for oceanic crust created at slow spreading ridges and seismic velocities and crustal thickness characteristic of Atlantic-type oceanic crust (White et al., 1992). 


\subsection{The central segment $\left(29^{\circ}-35^{\circ} \mathrm{N}\right)$}

This segment is marked by the ongoing collision between the African and Eurasian plates leading on land to the buildup of the Atlas system. The region is also affected by the Canary Island hotspot that has been active for the last $60 \mathrm{Ma}$ (Carracedo et al., 1998). Sedimentary layers in this region reflect these active processes and are marked by a high number of faults often reaching up to the surface.

One of the earliest geophysical cruises on this segment of the margin was carried out during the Conrad 2405 and 2406 cruises (Holik et al., 1991) during which 50 sonobuoy reflection and wideangle-seismic profiles were acquired (Figures 10 and 11). Detailed analysis of the extensive data set allowed imaging a basement bulge in the study area, and the presence of volcanic products in the sedimentary column associated with a region of high lower crustal velocities. The authors propose that the volcanism that was introduced by the passage of the Canary Island hotspot between 60 and $30 \mathrm{Ma}$ led to the deposition of volcanic ash layers and a high velocity volcanic residue underplate at the base of the crust, thereby thickening it and creating an up-warping of the basement.

In the same region off Safi and exactly conjugate to an existing wide-angle seismic profile on the Canadian margin, the SMART 1 profile (Funck et al., 2004), seven combined wide-angle and reflection seismic profiles were acquired during the MIRROR (2011) cruise using 25 ocean bottom seismometers and 15 land seismic stations (Figure 12) (Biari et al., 2015). The land stations image unthinned continental crust of $36 \mathrm{~km}$ thickness which is divided into three distinct layers of 15,12 and $9 \mathrm{~km}$ thickness (Figure $13 \mathrm{~A}$ ). Thinning of the continental crust occurs from 36 to $15 \mathrm{~km}$ over distances less than $90 \mathrm{~km}$.

West of the WACMA, slightly elevated lower crustal velocities in the oceanic domain were measured, which the authors interpret as atypical oceanic crust (or proto-oceanic crust). Further oceanward the crust is characterized by a thickness of about $8 \mathrm{~km}$ slightly higher than the crustal thickness of Atlantic-type oceanic crust and was modelled including high velocities at the base of the crust (Biari et al., 2015). The authors propose that these relatively high velocities $(>7.2 \mathrm{~km} / \mathrm{s}$ ) might be related to the existence of small pockets of serpentinite in the lower crust, rather than presenting exhumed and serpentinised upper mantle material. The seafloor is gently domed and the sedimentary layers show folding and minor thrust faulting suggestive of basin inversion and compression. No evidence for widespread magmatism such as sills and seaward dipping reflectors were identified, however, volcanic activity related to the Canary Island Hotspot, is imaged on multichannel seismic (MCS) profiles south of the study region.

\subsection{The North African salt basin $\left(35^{\circ} \mathrm{N}\right)$}

Between $32^{\circ}$ and $35^{\circ} \mathrm{N}$ the WACMA is located up to $150 \mathrm{~km}$ from the coast forming the north Moroccan salt basin. This basin has been subject of several reflection and wide-angle seismic surveys (Hinz et al., 1982; Maillard et al., 2006, Contrucci et al., 2004, Bartolome et al., 2005). One of the first cruises on this segment were the BGR Meteor-53 and Meteor-67 cruises (Hinz et al., 1982). The authors describe a 75-100 km wide basin containing salt diapirs and where sediments overlying the salt diapirs are deformed due to the influence of salt tectonics (Hinz et al., 1982). 
Wide-angle data from 14 OBS and 14 land stations off El Jadida acquired during the SISMAR cruise spanning the complete basin image in detail the transition from a 35-km-thick unthinned continental crust on the Moroccan platform to a $7 \mathrm{~km}$-thick oceanic crust over a distance of over $150 \mathrm{~km}$ (Figure 16). The unthinned continental crust is comprised of three layers of seismic velocities between 5.2-6.4, 6.6-6.8 and 6.8-7.0 $\mathrm{km} \mathrm{s}-1$, respectively. Four tilted fault blocks of continental crust comprise the continental slope, where the crust thins from 25 to $15 \mathrm{~km}$ (Figure 16A). At the base of the continental slope sedimentary thicknesses reach 4-6 km, including a 2-kmthick basal layer with a velocity of $4.0-4.5 \mathrm{~km}$. Three uppermost sedimentary layers are deformed by salt diapirs in the basin. A region of thinned crust approximately $50 \mathrm{~km}$ wide marks the transition from continental crust to normal oceanic crust, but this domain does not exhibit high P-wave velocities higher than 7.0 which would typically be associated with serpentinized upper mantle. Normal oceanic crust in the northwestern most $100 \mathrm{~km}$ of the model of profile 4 is $7 \mathrm{~km}$ thick, consistent with estimated spreading rates of $2 \mathrm{~cm} \mathrm{yr}-1$ or higher (Holik et al., 1991; Roeser et al., 2002). Upper mantle velocities are $8.00-8.20 \mathrm{~km} / \mathrm{s}$, excluding a high degree of mantle serpentinisation underneath the thin continental crust of the basin (Jaffal et al., 2009).

Remodelling of the SISMAR data set using tomographic approaches allowed to reinterprete velocity gradients and relocate the continent-ocean transition zone (Dehler et al., 2012; Sibuet et al., 2012). Together with the interpretation of industrial magnetic data the authors conclude, that the WACMA might be located about $15 \mathrm{~km}$ closer to the coast at the position of the SISMAR 04 profile, thereby leaving space to accommodate a sliver of originally Canadian plate at the western extremity of the basin (Sibuet et al., 2012).

Landward dipping reflectors identified in the reflection seismic sections were interpreted to be volcanic products and proposed to be associated to a lithospheric detachment fault originating from the opening of the ocean and separation of the North American from the African plate (Maillard et al., 2006).

\subsection{The Gulf of Cadiz}

The Northern Moroccan margin opened in a geodynamic setting differing from the Atlantic passive margin, by highly oblique rifting between the Iberian and African plates (Frizon de Lamotte, 2011) (Figure 17A). This rifting led to the creation of a small oceanic basin in the Gulf of Cadiz. The existence of an east-dipping subduction which migrated to its current position by the process of "slab roll-back" from a position much further east, thereby causing back-arc extension in the overriding plate was proposed to explain the existense of a dense lithospheric body in the Alboran Sea as well as rapid uplift of basement rocks in the same region during the Miocene (Gutscher $e t$ al., 2002; Gutscher et al., 2012; Lonergan and White, 1997) (Figure 17 B). The authors propose that this narrow subduction zone is still active, on the basis of apparent offsets observed in sediments at the seafloor imaged by MCS profiles (Figure 18). The presence of a STEP (Subduction-Transform Edge Propagator) fault behind this subduction first proposed by Govers and Wortel (2005) might have led to the observed paleomagnetic rotations on either side of the Gibraltar arc. These type of rotations are typically associated to of STEP faults. Structures originating from the passage of the fault can be traced eastward up to the continental margin off westernmost Algeria (Badji et al., 
2014).

The SISMAR 13 profile has a length of $320 \mathrm{~km}$ is located on the North African Margin and reached onto the Gulf of Cadiz basin (Figure 19) (Tiébot, 2005). Recent remodelling of the data set using the same methodology and only slight modifications resulted in a velocity model imaging the continent-ocean transition zone, although the determination of the crustal thickness in the basin itself was not possible based on the SISMAR data alone. However, using existing MCS data from the GC1 profile (Figure 18) and seismic velocities calculated to the east, as well as gravity modelling, allows us to constrain basement and Moho depth at the crossing between the two profiles (Tiébot, 2005). The continental crust, well constrained by the high quality landstation data is about $38 \mathrm{~km}$ in thickness and thins to $12 \mathrm{~km}$ thickness at model distance of $-80 \mathrm{~km}$. Extraction of velocity-depth profiles underneath the basement and comparison to values from compilations of thinned continental crust (Christensen and Mooney, 1995) imply, that the crust along this segment is of thinned continental origin. The neighbouring large crustal block is less well resolved (-140 to -80 $\mathrm{km}$ model distance), but has similar velocities and crustal velocity gradients as the thinned continental crust and is therefore probably of the same origin. No crustal refractions were observed between the up to $15-\mathrm{km}$-thick sedimentary sequence. Based on gravity modelling and crossing MCS data the crustal thickness here is between $8-10 \mathrm{~km}$ and probably of oceanic nature. On the crossing GC01 line the basement located at 9s TWT is flat and shows no blocks as would be expected for continental crust.

The Nearest-P2 wide-angle seismic profile allowed to define the crustal structure offshore SW Portugal and in the central Gulf of Cadiz (Sallares et al., 2011) (Figure 18). The resulting tomographic model images a $30 \mathrm{~km}$ thick continental crust beneath the Algarve coast, which thins towards the south, over a horizontal distance of $50 \mathrm{~km}$, down to a thickness $<7 \mathrm{~km}$. Here the crust shows a uniform thickness and a well-developed crust-mantle boundary, as well as seismic velocities and velocity gradients typical of oceanic crust (Sallares et al., 2011).

\section{Discussion}

The data from the SISMAR, DAKHLA and MIRROR surveys were acquired using nearly identical instruments and interpreted following the same methodology, which resulted in highly comparable velocity models, which allow imaging crustal structure variations along the complete margin. Direct comparison of the three final velocity models for the main transects allow us to constrain variations in the deep structure and the nature of the crustal layers (Figure 20).

All three transects were acquired combined with multi-channel seismic (MCS) profiles. The MCS data were processed including spherical divergence correction, frequency wavenumber filtering, bandpass filtering, internal mute and dynamic corrections and stacking. The last processing step included applying an automatic gain control and a Kirchoff time migration.

Comparison of the associated reflection seismic data reveals differences in the basement character in the continent ocean transition zone as well as differences in the sedimentary layering. The sedimentary basin imaged along the SISMAR 04 transect is underlain by continental crust, which is characterised by tilted fault blocks and numerous other faults (Figure 21). Here, the sedimentary layers are highly disturbed by salt tectonics. In comparison, the existence of salt domes along line 
MIRROR 01 is confined to a more narrow zone along the margin, with typical rough oceanic basement located directly at the margin foot. In the South along the DAKHLA N profile no salt domes are imaged, but instead a carbonate platform is located close to the coast (Figure 21).

\subsection{Continental domain : structure of the unthinned crust/width of zone of crustal thinning}

A comparison of the three wide-angle seismic profiles DAKHLA N, MI-01, and SISMAR 4 shows, that unthinned continental crustal thickness is about $7 \mathrm{~km}$ higher in the north. While three distinct layers have been identified in the northern profiles, only two layers were modelled on the southern profiles. The zone of continental crustal thinning is about $100 \mathrm{~km}$ in the south and central segments and up to $180 \mathrm{~km}$ wide in the profile SISMAR 4 where it forms a wide basin.

The crustal thickness variations found in these surveys is in good agreement with values from land seismic surveys (Figure 22). A crustal thickness of $40 \mathrm{~km}$ underneath the High Atlas was found by a deep seismic experiment using onshore and offshore dynamite explosions (Makris et al., 1985). The crustal thickness was found to decrease to $20 \mathrm{~km}$ in the offshore. A crustal thickness of $36 \mathrm{~km}$ close to the profile MI-01 increasing towards the Atlas Belt to up to $45 \mathrm{~km}$ were calculated from receiver function using teleseismic earthquakes (Spieker et al., 2014). Towards the south the crustal thickness decreases to $27 \mathrm{~km}$ at the Souss Basin.

A high amplitude sub-moho reflector has been imaged in the zone of continental crustal tinning offshore Agadir and Safi (Makris et al., 1985, Biari et al., 2015) at a depth of 75-80 and 80-85 km respectively. It therefore corresponds roughly to the depth of the lithosphere-asthenosphere boundary (LAB) proposed from geoid and thermal analysis (Fullea et al., 2010). This unusually shallow depth of the LAB is proposed to result from mantle partial melting beneath the Canary volcanic Islands (Makris et al., 1985) and might therefore have modified the crustal structure in the region of the Tafelney Plateau and the High Atlas (Benabdellouahed et al., submitted). Flow of mantle material from the Canary hotspot into a sub-continental lithospheric corridor underneath the Atlas into the Western Mediterranean region was proposed based on geochemical analysis of volcanic products of lavas from the Canary Islands and from the Middle Atlas to the Western Mediterranean region (Duggen et al., 2009).

\subsection{The ocean-continent transition zone}

On passive volcanic margins the thinned continental and oceanic crust are separated by an oceancontinent transition zone (OCT). In this region often the seismic velocities of the crustal layers is in between those of continental and those of oceanic crust. While on magma-poor margins velocities between 7.4 and $7.8 \mathrm{~km} / \mathrm{s}$ are commonly interpreted as serpentinised mantle material, exhumed during breakup (Dean et al., 2000; Funck et al., 2004; Van Avendonk et al., 2006), similar velocities measured on volcanic margins are proposed to be volcanic residues from volcanism underplating or intruding the crust (Mjelde et al., 2009; Bauer et al., 2000) or sill intrusions into the lower crust (White et al., 2008).

Along the NW African margin the ocean-continent transition zone is between 30 and $50 \mathrm{~km}$ wide and separates highly thinned continental crust from crust originating from oceanic accretion. Velocity-depth profiles extracted in the transition zone show relatively low velocity gradients, 
which would be in favour of an interpretation as thinned continental crust, but also velocities close to normal oceanic crust of compilations for Atlantic type crust (White et al., 1992), indicating an oceanic origin. Zones of exhumed upper mantle as imaged along the Iberian Abyssal Plain (Dean et al., 2000), the passive continental margin off Canada (Funck et al., 2004, Van Avendonk et al., 2006) show lower upper basement velocities including a higher gradient, and thinner crustal thickness than the Atlantic margin off Morocco. In the study region no zone of igneous underplating has been identified at the OCT. Some elevated lower crustal velocities were interpreted as resulting from igneous intrusions during rifting.

\subsection{Oceanic crust : thickness, composition, basement topography}

The spreading velocity is related to the lower crustal velocity through various processes, such as mantle upwelling leading to differences in melt supply or the incorporation of upper mantle material into the crust at low spreading rates. The first process predicts that the composition and following also the velocity structure of igneous crust produced is influenced by the temperature and upwelling rate of the mantle, which constrains the degree of adiabatic decompression and the volume of melt (Korenaga et al., 2002, Kelemen and Holbrook, 1995, Leinweber et al., 2013). At low spreading rates, gabbros which appear to make up most of the lower oceanic crust at spreading rates higher than $10 \mathrm{~mm}$ yr-1 half rate, may be retained deeper in the mantle lithosphere (Lizarralde et al. 2004). The very thin oceanic crust formed at ultraslow spreading centres might therefore consist of a thin volcanic layer on top of serpentinized mantle rocks (Minshull et al. 1998; Jokat \& SchmidtAursch, 2007; Jokat et al. 2012), resulting in elevated seismic velocities of the lower crust.

Spreading rates in the central Atlantic were generally low at the onset of accretion, with 0.8 or 0.5 cm/yr half spreading (Labails et al., 2010; Schettino and Turco, 2009; Roeser et al., 2002)). Higher velocities are proposed to have existed between M25 and M22 in the late Jurassic probably caused by a major plate reorganisation (Labails et al., 2010). These decreased to $1.3 \mathrm{~cm} / \mathrm{yr}$ at M22 and kept constant up to M0. Variation in the basement roughness observed on reflection seismic profiles are probably due to variations in the spreading velocity (Ranero and Banda, 1997). The region was later on affected by volcanism due to the Canary Islands and Cape Verde Islands hotspots. Basement has formed bulges possibly due to the hotspot influence (Holik et al., 1991; Duggen et al., 2009; Patriat and Labails, 2006; Neumaier et al., 2015).

A zone of high lower crustal velocities is located between the WACMA and M25 magnetic anomalies, in the oldest oceanic crust. It was originally identified based on sonobuoy data (Holik et al., 1991) and later identified in the DAKHLA and MIRROR data sets. It has been proposed to consist of volcanic underplate associated with the passage of the Canary Island Hotspot (Holik et $a l ., 1991)$. The location of this zone of high lower crustal velocities between WACMA and M25 south of the Canary Islands led to the proposition, that it might rather be connected to very slow spreading at the onset of seafloor spreading or to a more mafic composition due to slightly elevated mantle temperatures during accretion (Klingelhoefer et al., 2009). MCS data from DAKHLA Profile $\mathrm{N}$ show a smooth basement and numerous dipping reflectors in the region of high lower crustal velocities $(7.00-7.40 \mathrm{~km} / \mathrm{s})$, which change to a more rough more typical oceanic crust at the location of Tropical Seamount at the position of M25. 
A basement bulge is located west of the region of high lower crustal velocities and smooth basement and spans N-S from the Canary to Cape Verde Islands. The bulge does not parallel seafloor isochrons, and might thus indicate a relation between both hotspots (Patriat and Labails, 2006). The detailed analysis of existing reflection seismic profiles also led to the proposition that smooth seafloor is restricted to the vicinity of volcanic edifices, such as the Saharan Seamounts and Tropical seamount (Figure 7).

A similar zone of unusual smooth seafloor was detected on multi-channel seismic data west of the Canary Islands between anomaly M25 and M16 (Ranero and Banda, 1997). The transition to rough basement is gradual and the fabric is proposed to be related to the spreading velocity at the time of creation of the seafloor. High spreading velocities lead to the generation of smoother seafloor (Menard, 1967; Malinverno, 1991). One region south west of the Canary Islands is supposed to have been affected by the passage of the Cape Verde Hotspot, however, this hypothesis was based on early plate kinematic reconstructions (Morgan, 1983) whereas modern reconstructions do not place the hotspot track of the Cape Verde islands in this region (eg. Mueller et al., 1993).

\subsection{Volcanism : volcanism associated with the Canary Hot Spot and to the initial opening}

Among the volcanic products identified along the NE African margin are volcanic layers dipping landward along the SISMAR 10 profile (Maillard et al., 2006) proposed to result from initial opening of the Atlantic and to be the source of the S1 magnetic anomaly and volcanic ash layers imaged in MCS data from the Conrad cruise and proposed to be associated to the passage of the Canary Island Hotspot in the region (Holik et al., 1991). A variety of volcanic seamounts and islands are located in the vincinity of the Canary Islands and between the Canary and Cape Verde islands (eg. Ye et al., 1999; Patriat and Labails, 2006) (Figure 25A).

A weak series of seaward dipping reflectors in the uppermost part of the basement and underneath the S1 magnetic anomaly and probably representing lava flows were identified in seismic data along the Moroccan margin (Roeser et al., 1992, Maillard et al., 2006) They might be the origin of the S1 magnetic anomaly (Roeser et al., 1992). Seaward of S1 is a 70-km-wide strip of horizontal reflectors that become landward dipping to the west in the uppermost part of the basement; it parallels S1 over a distance of $200 \mathrm{~km}$ and may indicate excessive magma supply within the first 2 m.y. of seafloor spreading (Roeser et al., 1992) (Figure 25B).

Originally, the Canary Islands were interpreted as having been generated by a broad mantle upwelling under a slow moving or stable plate resulting in spatial and temporal more diffuse volcanic activity and a large number of seamounts and islands distributed over a wide region (Schmincke, 1982). A volcanic ash layer was identified along the trail of the Canary Island hotspot trail (Holik et al., 1991) (Figure 25C). Also, both the Canary Islands and the Moroccan margin show a low elastic thickness of the lithosphere (Watts, 1994), which can be explained by the influence of a mantle hotspot since the slow absolute African plate motions has allowed sufficient time for heat transfer in the region from the asthenosphere to the lithosphere and thereby causing thermal weakening (Watts, 1994). However, today, the origin of the Canary Islands is still disputed, as the islands themselves are not located on a topographic swell as usually found for hotspots (Lustrino 
and Wilson, 2007 and references therein). On the basis of geochemical data it has been proposed that hot material from the Canary mantle plume travels along a subcontinental lithospheric corridor to the western Mediterranean, thereby leaving a trail of intraplate volcanism (Duggen et al. 2009). An alternative hypothesis for the origin of this flow based on analogue models is that a part of the Canary Hotspot was captured by the Gibraltar subduction zone by slab rollback induced toroidal mantle flow (Mériaux et al., 2015).

\subsection{Comparison to the conjugate North American margin}

The margin conjugate to the NW African margin is the North American margin, that is characterised by a transition from typical volcanic margin in the south (U.S. East Coast) (Holbrook and Kelemen, 1993) to non-volcanic continental margin in the North (Newfoundland et Labrador) (Funck et al., 2004). In the south a thick layer of underplate has been image by wide-angle seismic profiles (Holbrook and Kelemen, 1993). In reflection seismic profiles SDR of a volume of up to $3.2 \times 10^{6}$ $\mathrm{km}^{3}$ have been identified (Holbrook and Kelemen, 1993 ; Oh et al., 1995).

Towards the north in the Baltimore Basin, a multi-channel seismic profile combined with 6 expanding spread profiles (ESP) were acquired during the LASE cruise (Diebold et al., 1988) located as a conjugate to the DAKHLA study region (Figures 26 and 27). Although data quality is not as high as on modern wide-angle seismic surveys, the deep structure shows some similarities. The continental crust thins on both margins along a short distance of around $100 \mathrm{~km}$. In the sedimentary basin of the American margin, some layers of high seismic velocities have been imaged and interpreted as a carbonate bank (Diebold et al., 1988) as has been proposed for the DAKHLA region. The deep structure of the margin on the African side differs from the conjugate Baltimore Canyon margin, as the Moho rise, which is generally located directly underneath the region where the increase of basement depth is highest, is offset about $50 \mathrm{~km}$ towards the ocean. This asymmetrical structural morphology is proposed to be due to regional tectonic inheritance (Labails and Olivet, 2009) or to thickening of the lower crust through intrusions (Klingelhoefer et al., 2009). Similar to the DAKHLA Profile $\mathrm{N}$ the neighbouring oceanic crust is characterised by high lower crustal velocities $(7.2-7.4 \mathrm{~km} / \mathrm{s})$, as compared to normal oceanic crust. The crust in this region is interpreted to be oceanic in origin, about $10 \mathrm{~km}$ thick and thinning to $7 \mathrm{~km}$ further oceanward similar to typical oceanic crust (White et al., 1992). The structure of the oceanic crust in the west of the sedimentary basin is very similar to the oceanic crust imaged in the east of the sedimentary basin off DAKHLA, including high velocities at the base and a relatively smooth basement. The LASE profile does not reach normal oceanic crust, which is imaged west of the M25 magnetic anomaly in the DAKHLA study region.

Further north offshore Nova Scotia, the character of the margin changes to a less volcanic style. Here, the amplitude of the ECMA decreases and is not identifiable further north-east. The three SMART wide-angle seismic profiles are located in this region. Whereas the MIRROR profiles are conjugate to the SMART 1 profile (Figure 28), the SISMAR profiles are located in the northern Moroccan salt basin which has no conjugate on the North American margin.

Comparison of the SMART 1 profile with the exact conjugate MIRROR 01 profile, shows that the crustal geometry of the unthinned continental crust is very similar, with a thickness of about $35 \mathrm{~km}$ 
divided into three layers. Geometry of crustal thinning is equally similar to a thickness of about $10 \mathrm{~km}$. While on the African Margin oceanic crust neighbours continental crust of about 10-12 km thickness, on the American Margin crustal the continental crust is thinned to as little as 2 to $4 \mathrm{~km}$ thickness. In this region the very thin continental crust is underlain by serpentinised upper mantle material. Probably water descending in fractures through this thin crust is responsible for the serpentinisation. Further oceanward along the SMART 1 profile a region of exhumed upper mantle has been imaged. It is proposed to result from initial rifting. No such region could be imaged along the MIRROR profiles. Although, high velocities in the lower crust are also imaged in the MIRROR data set, the existence of strong reflections from the base of the crust in the MIRROR data set seem to indicate that these are due to inclusion of serpentinite pockets into proto-oceanic crust rather than exhumed upper mantle, which would give rise to no or only weak reflections at its base.

The thickness of the initial oceanic crust is higher on the African side $(8 \mathrm{~km})$ than on the Canadian side $(<3 \mathrm{~km})$ and velocities of the oceanic crust are lower on the Candian than on the African side. Both observations could be explained by asymmetric accretion at the onset of oceanic spreading. During asymmetric accretion of oceanic crust (e.g., Escartín et al., 2008), the hanging wall (African side) is influenced by the neo-volcanic zone producing a typical layered oceanic crust, while the footwall (Canadian side) consists mainly of exhumed serpentinite with intruded gabbros. Further on, the African line shows an intra-crustal reflector at about 1s TWT below basement. This could be interpreted as the oceanic boundary between layer 2 and layer 3 . This reflector cannot be seen on the Canadian profile - this fact can also be explained by asymmetric oceanic accretion with eastward dipping detachments. A high degree of serpentinization can explain the upper crustal velocities in the range of 4.5 to $5.0 \mathrm{~km} / \mathrm{s}$ as reported for line SMART-1. Cannat et al. (2006) have shown that such asymmetric processes can be stable for several tens of millions of years.

A second explanation might be that oceanic crust along the African margin has undergone modifications at a later stage. While sediments are undisturbed on the Canadian margin, they show intense faulting on the African side, where faults penetrate the complete sedimentary section up to the seafloor (Figure 29). This faulting might be related to uplift of the basement, which has been proposed to result from thermal anomalies related to the Canary Island Hotspot (Holik et al., 1991; Duggen et al., 2009). So one alternative explanation of the difference in oceanic crustal thickness could be that the oceanic crust sampled along the MIRROR profiles was later modified and thickened by melt extracted from the Canary Hotspot (Holik et al., 1991).

Anyhow, these explanations remain speculative, since a ridge jump at BSMA time cannot be ruled out. In this case the conjugate oceanic crust to profile MIRROR-01 would lie eastward of the area covered by line SMART-1.

\section{Conclusions}

This compilation of new and existing data sets from the Moroccan passive continental margin reveals major along-strike variations in its deep structure. The unthinned continental crust in the Gulf of Cadiz region and along the northern Moroccan margin has a thickness varying between 35 and $37 \mathrm{~km}$. It thins toward the south to only $27 \mathrm{~km}$ offshore DAKHLA. In the south crustal thinning takes place in a narrow zone of $90 \mathrm{~km}$ with the upper crust thinning closer to the continent than the 
lower crust, probably due to depth-dependent stretching and the presence of the Precambrian Reguibat Ridge on land (Klingelhoefer et al., 2009). The North Moroccan Basin is underlain by highly thinned continental crust of only 6-8 $\mathrm{km}$ thickness up to the position of the WACMA magnetic anomaly (Contrucci et al., 2004). Correspondingly the width of the zone of crustal thinning is wider in the north narrowing to the south. This difference indicates that rifting and initial opening of the oceanic basin has not followed identical mechanisms from north to south.

The ocean-continent transition zone shows a variable width between 40 and $70 \mathrm{~km}$. Comparison of the seismic velocities in this zone with those of thinned continental crust, exhumed upper mantle and typical oceanic velocities indicates that rocks in this zone are probably of a mixed origin between continental and oceanic rocks. Some elevated velocities are proposed to be associated to pockets of serpentinite or volcanic intrusions. No underplate bodies directly associated to the initial break-up have been imaged along this part of the continental margin. The oceanic crust west of the OCT is characterised by a thickness of 7-8 km along the complete margin, with high velocities of up to $7.5 \mathrm{~km} / \mathrm{s}$ between magnetic anomalies S1 and M25, which are associated to a flat basement reflector in the south of the study region. The elevated velocities at the base of the crust in this region are proposed to be related to from inclusions of serpentinite intro proto-oceanic crust during the onset of spreading. The change to more typical oceanic crust at magnetic anomaly M25 is probably related to changes in the spreading velocities at the time of the Kimmeridgian/Tithonian plate reorganisation (Labails et al., 2010).

Different types of volcanic products have been imaged along the margin, including ash layers, volcanic seamounts with assciated dikes and sills, and seaward dipping reflectors (Holik et al., 1992; Roeser et al., 2002). While the former are confined to the region next to the Canary Islands, and is thus not related to the initial opening of the oceanic, some SDRs are proposed to be the origin of the S1 magnetic anomaly. However, the SDRs are underdeveloped and are not a predominant feature present continuously along the complete margin which was associated to only weak volcanism (Contrucci et al., 2004; Klingelhoefer et al., 2009, Biari et al., 2015).

The conjugate passive margin of Nova Scotia is characterised by a decrease of the amount of volcanism associated to the original break-up from the south to the north. The amplitude of the East Coast Magnetic anomaly decreases and vanishes at the latitude of $44^{\circ} \mathrm{N}$. Comparison of both margins shows a similar continental crustal thickness and structure, however 3-4 km thinner oceanic crust on the American side than on the African margin (Funck et al., 2004; Biari et al., 2015). A zone of interpreted very thin continental crust underlain by serpentinised upper mantle present on the Canadian margin is not imaged along the NW African margin. The higher thickness might also result from volcanic underplateing due to the presence of the Canary hotspot in the region between 60 to $30 \mathrm{Ma}$.

Among the remaining open questions along the NW African margin is the question of the origin of the S1 or WACMA magnetic anomaly. No magmatic underplate and only few SDRs have been imaged in the region of the anomaly (Roeser et al., 2002; Biari et al., 2015). Detailed cartography of the magnetic anomalies might confirm the proposed existence of a magnetic anomaly conjugate to the Blake Spur anomaly (Labails and Olivet, 2010). The existence of such an anomaly might 
decide discussions about the proposed ridge jump at the BSMA time (Klitgord and Schouten, 1986). Further work along this margin might allow to fill existing gaps in the seismic coverage between the Canary Islands and the continental margin. New data would permit to better constrain the thinning of the continental crust from north to south. They could also be used to verify the existence of a flow of mantle material from the Canaries underneath the Atlas and thereby answer questions about the origin of the high isostatically uncompensated topography of the mountain range.

Lastly, more work is required to identify the exact nature of the rocks of the ocean-continent transition zone along both conjugate margins. This would require the acquisition of more seismic data in the OCT but final answers can only come from drilling.

\section{Acknowledgements}

We thank the Captains and crews of the vessels involved in the acquisition of all of this data, and without whose efforts, this wealth of new data could never have been acquired, as well as the seismic and OBS teams. We also thank many other Moroccan, French, German and Portuguese colleagues who have contributed significantly to the collective efforts to advance our understanding of the tectonics along this complex margin. The GMT (Wessel and Smith, 1995) and Seismic Unix (Stockwell, 1999) software packages were used in the preparation of this paper. The GPlates software from the EarthByte Project was used to create the plate-tectonic reconstructions. We would like to thank Tim Minshull and Mohamad Hafid for constructive and detailed reviews which helped improve the manuscript. 


\section{References}

Badji, R., Charvis, P., Bracene, R., Galve, A., Badsi, M., Ribodetti, A., Benaissa, Z., Klingelhoefer, F., Medaouri, M., \& Beslier, M. O. (2015). Geophysical evidence for a transform margin offshore Western Algeria: a witness of a subduction-transform edge propagator?. Geophysical Journal International, 200(2), 1029-1045.

Bartolome, R., Contrucci, I., Nouzé, H., Thiebot, E., \& Klingelhoëfer, F. (2005). Using the OBS wide-angle reflection/refraction velocities to perform a pre-stack depth migration image of the "single bubble" multichannel seismic: Example of the Moroccan margin. Journal of applied geophysics, 57(2), 107-118.

Bauer, K., Neben, S., Schreckenberger, B., Emmermann, R., Hinz, K., Fechner, N., Gohl, K., Schulze, A., Trumbull, R. B. \& Weber, K. (2000). Deep structure of the Namibia continental margin as derived from integrated geophysical studies. Journal of Geophysical Research, vol. 105, B11, 25829-25853.

Benabdellouaheda, M., Klingelhoefer, F., Gutscher, M.-A., Rabineau, M., Hafid, M., Biari, Y., Duarte, J.-C., Schnabel, M., Baltzer, A., Pedoja, K., Reichert, C., Sahabi, M., Recent uplift of the Atlantic Atlas (Offshore West Morocco): Tectonic arch and submarine terraces, submitted to Tectonophysics.

Biari, Y., Klingelhoefer, F., Sahabi, M., Aslanian, D., Schnurle, P., Berglar, K., K. Berglar, K., Moulin, M., Mehdi, K., Graindorge, D., Evain, M., Benabdellouahed, M., \& Reichert, C. (2015). Deep crustal structure of the North-West African margin from combined wide-angle and reflection seismic data (MIRROR seismic survey). Tectonophysics, 656, 154-174.

Bonvalot, S., Balmino, G., Briais, A., Kuhn, M., Peyrefitte, A., \& Vales, N. (2012). World Gravity Map, 1: 50000000 map/Eds. BGI-CGMW-CNES-IRD. Paris, 2012. http://bgi. obs-mip. fr/activities/Projects/world_gravity_map_wgm.

Bullard, E., Everett, J. E., \& Smith, A. G. (1965). The fit of the continents around the Atlantic. Philosophical Transactions of the Royal Society of London A: Mathematical, Physical and Engineering Sciences, 258(1088), 41-51.

Cannat, M., D. Sauter, V. Mendel, E. Ruellan, K. Okino, J. Escartin, V. Combier, and M. Baala (2006), Modes of seafloor generation at a melt-poor ultraslow-spreading ridge, Geology, 34(7), 605-608, doi:10.1130/g22486.1.

Cande, S. C., \& Kent, D. V. (1995). Revised calibration of the geomagnetic polarity timescale for the Late Cretaceous and Cenozoic. Journal of Geophysical Research, 100(B4), 6093-6095.

Carracedo, J. C., Day, S., Guillou, H., Rodríguez Badiola, E., Canas, J. A., \& Pérez Torrado, F. J. (1998). Hotspot volcanism close to a passive continental margin: the Canary Islands. Geological Magazine, 135(05), 591-604.

Christensen, N., \& Mooney, W. (1995). Seismic velocity structure and composition of the continental crust: A global view. Journal of Geophysical Research Atmospheres, (100), 9761- 
9788.

Contrucci, I., Klingelhöfer, F., Perrot, J., Bartolome, R., Gutscher, M. A., Sahabi, M., Malod, J., \& Rehault, J. P. (2004). The crustal structure of the NW Moroccan continental margin from wideangle and reflection seismic data. Geophysical Journal International, 159(1), 117-128.

Dean, S. M., Minshull, T. A., Whitmarsh, R. B., \& Louden, K. E. (2000). Deep structure of the ocean- continent transition in the southern Iberia Abyssal Plain from seismic refraction profiles: The IAM- 9 transect at $4020^{\prime}$ N. Journal of Geophysical Research: Solid Earth (1978-2012), 105(B3), 5859-5885.

Dehler (2012) Initial rifting and breakup between Nova Scotia and Morocco: insight from new magnetic models, CJES Special Issue on the theme of Mesozoic-Cenozoic geology of the Scotian Basin.

Dewey, J. F., Helman, M. L., Knott, S. D., Turco, E., \& Hutton, D. H. W. (1989). Kinematics of the western Mediterranean. Geological Society, London, Special Publications, 45(1), 265-283.

Diebold, J. B. (1996). Digitization and Reanalysis of Analog Sonobuoy Records (No. 5-21720). Trustees of Columbia Univ. New York.

Drake, C. L., Ewing, M., \& Sutton, G. H. (1959). Continental margins and geosynclines: the east coast of North America north of Cape Hatteras. Physics and Chemistry of the Earth, 3, 110-198.

Duggen, S., Hoernle, K. A., Hauff, F., Kluegel, A., Bouabdellah, M., \& Thirlwall, M. F. (2009). Flow of Canary mantle plume material through a subcontinental lithospheric corridor beneath Africa to the Mediterranean. Geology, 37(3), 283-286.

Escartín, J., D. K. Smith, J. Cann, H. Schouten, C. H. Langmuir, and S. Escrig (2008), Central role of detachment faults in accretion of slow-spreading oceanic lithosphere, Nature, 455(7214), 790794, doi:10.1038/nature07333.

Frizon de Lamotte, D., Raulin, C., Mouchot, N., Wrobel- Daveau, J. C., Blanpied, C., \& Ringenbach, J. C. (2011). The southernmost margin of the Tethys realm during the Mesozoic and Cenozoic: Initial geometry and timing of the inversion processes. Tectonics, 30(3).

Fullea, J., Fernàndez, M., Afonso, J. C., Vergés, J., \& Zeyen, H. (2010). The structure and evolution of the lithosphere-asthenosphere boundary beneath the Atlantic-Mediterranean Transition Region. Lithos, 120(1), 74-95.

Funck, T., Jackson, H. R., Louden, K. E., Dehler, S. A., \& Wu, Y. (2004). Crustal structure of the northern Nova Scotia rifted continental margin (eastern Canada). Journal of Geophysical Research: Solid Earth (1978-2012), 109(B9).

Govers, R., \& Wortel, M. J. R. (2005). Lithosphere tearing at STEP faults: response to edges of subduction zones. Earth and Planetary Science Letters, 236(1), 505-523.

Gutscher, M. A., Malod, J., Rehault, J. P., Contrucci, I., Klingelhoefer, F., Mendes-Victor, L., \& Spakman, W. (2002). Evidence for active subduction beneath Gibraltar. Geology, 30(12), 1071- 
1074.

Gutscher, M. A., Dominguez, S., Westbrook, G. K., Le Roy, P., Rosas, F., Duarte, J. C., Terrinha, P., Miranda, J. M., Graindorge, D., Gailler, A., Sallares, V., \& Bartolomé, R. (2012). The Gibraltar subduction: A decade of new geophysical data. Tectonophysics, 574, 72-91.

Goldflam, P., Hinz, K., Weigel, W., Wissmann, G., \& Blundell, D. J. (1980). Some features of the northwest African margin and magnetic quiet zone. Philosophical Transactions of the Royal Society of London A: Mathematical, Physical and Engineering Sciences, 294(1409), 87-96.

Jabbour, H., \& Tari, G. (2007). Subsalt exploration potential of the Moroccan salt basin. The Leading Edge, 26(11), 1454-1460.

Heezen, B. C., Ewing, M., \& Miller, E. T. (1953). Trans-Atlantic profile of total magnetic intensity and topography, Dakar to Barbados. Deep Sea Research (1953), 1(1), 25-33.

Hinz, K., Dostmann, H., \& Fritsch, J. (1982). The continental margin of Morocco: seismic sequences, structural elements and geological development. In Geology of the Northwest African continental margin (pp. 34-60). Springer, Berlin Heidelberg.

Hoernle, K. A. J., \& Schmincke, H. U. (1993). The role of partial melting in the 15-Ma geochemical evolution of Gran Canaria: a blob model for the Canary hotspot. Journal of Petrology, 34(3), 599-626.

Holbrook, W. S., \& Kelemen, P. B. (1993). Large igneous province on the US Atlantic margin and implications for magmatism during continental breakup. Nature, 364(6436), 433-436.

Holik, J. S., Rabinowitz, P. D., \& Austin, J. A. (1991). Effects of Canary Island Hotspot volcanism on structure of oceanic crust off Morocco. Journal of Geophysical Research: Solid Earth (19782012), 96(B7), 12039-12067.

Jaffal, M., Klingelhoefer, F., Matias, L., Teixeira, F., \& Amrhar, M. (2009). Crustal structure of the NW Moroccan margin from deep seismic data (SISMAR Cruise). Comptes Rendus Geoscience, 341(6), 495-503.

Jokat, W., \& Schmidt- Aursch, M. C. (2007). Geophysical characteristics of the ultraslow spreading Gakkel Ridge, Arctic Ocean. Geophysical journal international, 168(3), 983-998.

Jokat, W., Kollofrath, J., Geissler, W. H., \& Jensen, L. (2012). Crustal thickness and earthquake distribution south of the Logachev Seamount, Knipovich Ridge. Geophysical Research Letters, 39(8).

Keen, C. E., \& Potter, D. P. (1995a). Formation and evolution of the Nova Scotian rifted margin: evidence from deep seismic reflection data. Tectonics, 14(4), 918-932.

Keen, C. E., \& Potter, D. P. (1995b). The transition from a volcanic to a nonvolcanic rifted margin off eastern Canada. Tectonics, 14(2), 359-371.

Kelemen, P. B., \& Holbrook, W. S. (1995). Origin of thick, high- velocity igneous crust along the US East Coast Margin. Journal of Geophysical Research: Solid Earth, 100(B6), 10077-10094. 
Keller, F., Meuschke, J. L., \& Alldredge, L. R. (1954). Aeromagnetic surveys in the Aleutian, Marshall, and Bermuda islands. Eos, Transactions American Geophysical Union, 35(4), 558-572.

Kent, D. V., \& Gradstein, F. M. (1986). A Jurassic to recent chronology. The Western North Atlantic Region, 45-50.

Klingelhoefer, F., Labails, C., Cosquer, E., Rouzo, S., Geli, L., Aslanian, D., Olivet, J.-L., Sahabi, M., Nouze, H,. \& Unternehr, P. (2009). Crustal structure of the SW-Moroccan margin from wideangle and reflection seismic data (the DAKHLA experiment) Part A: Wide-angle seismic models. Tectonophysics, 468(1), 63-82.

Klitgord, K. D., \& Schouten, H. (1986). Plate kinematics of the central Atlantic. In: The geology of North America, 1000, 351-378.

Korenaga, J., Kelemen, P. B., \& Holbrook, W. S. (2002). Methods for resolving the origin of large igneous provinces from crustal seismology. Journal of Geophysical Research: Solid Earth, 107(B9).

Labails, C., \& Olivet, J. L. (2009). Crustal structure of the SW Moroccan margin from wide-angle and reflection seismic data (the DAKHLA experiment). Part B-The tectonic heritage. Tectonophysics, 468(1), 83-97.

Labails, C., Olivet, J. L., Aslanian, D., \& Roest, W. R. (2010). An alternative early opening scenario for the Central Atlantic Ocean. Earth and Planetary Science Letters, 297(3), 355-368.

Leinweber, V. T., Klingelhoefer, F., Neben. S., Reichert, C., Aslanian, D., Matias, L., Heyde, I., Schreckenberger, B., and Jokat, W. (2013) The crustal structure of the Central Mozambique continental margin - Wide-angle seismic, gravity and magnetic study in the Mozambique Channel, Eastern Africa. Tectonophysics, 599, 170-196.

Lizarralde, D., Gaherty, J. B., Collins, J. A., Hirth, G., \& Kim, S. D. (2004). Spreading-rate dependence of melt extraction at mid-ocean ridges from mantle seismic refraction data. Nature, 432(7018), 744-747.

Le Roy, P., Pique, A., Le Gall, B., Brahim, L. A., Morabet, A. M., \& Demnati, A. (1997). Les bassins cotiers triasico-liasiques du Maroc occidental et la diachronie du rifting intra-continental de l'Atlantique central. Bulletin de la Société géologique de France, 168(5), 637-648.

Le Roy, P. (1997). Les bassins ouest-marocains; leur formation et leur évolution dans le cadre de l'ouverture et du développement de l'Atlantique central(marge africaine) (Ph. D. Thesis).

Louden, K., Wu, Y., \& Tari, G. (2013). Systematic variations in basement morphology and rifting geometry along the Nova Scotia and Morocco conjugate margins. Geological Society, London, Special Publications, 369(1), 267-287.

Luheshi, M., Roberts, D. G., Nunn, K., Makris, J., Colletta, B., Wilson, H., Monnier, F., Rabary, G. \& Dubille, M. (2012). The impact of conjugate margins analysis on play fairway evaluation-an analysis of the hydrocarbon potential of Nova Scotia. First Break, 30(1), 61-72. 
Lustrino, M., \& Wilson, M. (2007). The circum-Mediterranean anorogenic Cenozoic igneous province. Earth-Science Reviews, 81(1), 1-65.

Maillard, A., Malod, J., Thiébot, E., Klingelhoefer, F., \& Réhault, J. P. (2006). Imaging a lithospheric detachment at the continent-ocean crustal transition off Morocco. Earth and Planetary Science Letters, 241(3), 686-698.

Makris, J., A. Demnati, and J. Klussmann (1985), Deep seismic soundings in Morocco and a crust and upper mantle model deduced from seismic and gravity data, Ann. Geophys., 3, 369-380.

Malinverno, A. (1991). Inverse square-root dependence of mid-ocean-ridge flank roughness on spreading rate. Nature 352, 58 - 60; doi:10.1038/352058a0

Maus, S., Barckhausen, U., Berkenbosch, H., Bournas, N., Brozena, J., Childers, V., ... \& Caratori Tontini, F. (2009). EMAG2: A 2-arc min resolution Earth Magnetic Anomaly Grid compiled from satellite, airborne, and marine magnetic measurements. Geochemistry, Geophysics, Geosystems, 10(8).

Menard, H. W. (1967). Sea floor spreading, topography, and the second layer. Science, 157(3791), 923-924.

Mériaux, C. A., Duarte, J. C., Duarte, S. S., Schellart, W. P., Chen, Z., Rosas, F., Mata, J., Schellart, W. P., \& Terrinha, P. (2015). Capture of the Canary mantle plume material by the Gibraltar arc mantle wedge during slab rollback. Geophysical Journal International, 201(3), 1717-1721.

Minshull, T. A., Muller, M. R., Robinson, C. J., White, R. S., \& Bickle, M. J. (1998). Is the oceanic Moho a serpentinization front?. Geological Society, London, Special Publications, 148(1), 71-80.

Mjelde, R., Faleide, J. I., Breivik, A. J., \& Raum, T. (2009). Lower crustal composition and crustal lineaments on the Vøring Margin, NE Atlantic: a review. Tectonophysics, 472(1), 183-193.

Morgan, W. J. (1983). Hotspot tracks and the early rifting of the Atlantic. Tectonophysics, 94(1), 123-139.

Müller, R. D., Royer, J. Y., \& Lawver, L. A. (1993). Revised plate motions relative to the hotspots from combined Atlantic and Indian Ocean hotspot tracks. Geology, 21(3), 275-278.

Neumaier, M., Back, S., Littke, R., Kukla, P. A., Schnabel, M. and Christian Reichert (2015) Late Cretaceous to Cenozoic geodynamic evolution of the Atlantic margin offshore Essaouira (Morocco), Basin Research, 1-19, doi: 10.1111/bre.12127

Oh, J., Austin, J. A., Phillips, J. D., Coffin, M. F., \& Stoffa, P. L. (1995). Seaward-dipping reflectors offshore the southeastern United States: Seismic evidence for extensive volcanism accompanying sequential formation of the Carolina trough and Blake Plateau basin. Geology, 23(1), 9-12.

Olivet, J.-L. (1978) Nouveau modèle d'évolution de l'Atlantique nord et central (Ph. D. Thesis, Université de Pierre et Marie Curie, Paris, 150 p.

Olivet, J.-L. (1984) Cinematique de l'Atlantique nord et central; Centre National pour l'exploration 
des océans, Rapport scientifiques et techniques de l'Ifremer, No. 54, 108 p.

Patriat, M., \& Labails, C. (2006). Linking the Canary and Cape-Verde hot-spots, northwest Africa. Marine Geophysical Researches, 27(3), 201-215.

Pitman, W. C., \& Talwani, M. (1972). seafloor spreading in the North Atlantic. Geological Society of America Bulletin, 83(3), 619-646.

Ranero, C. R., Banda, E., \& Buhl, P. (1997). The crustal structure of the Canary Basin: Accretion processes at slow spreading centers. Journal of Geophysical Research: Solid Earth (1978-2012), 102(B5), 10185-10201.

Roeser, H. A., Steiner, C., Schreckenberger, B., \& Block, M. (2002). Structural development of the Jurassic Magnetic Quiet Zone off Morocco and identification of Middle Jurassic magnetic lineations. Journal of Geophysical Research: Solid Earth (1978-2012), 107(B10), EPM-1.

Roeser, H. A. (1982). Magnetic anomalies in the magnetic quiet zone off Morocco. In Geology of the northwest African continental margin (pp. 61-68). Springer Berlin Heidelberg.

Roest, W. R., Danobeitia, J. J., Verhoef, J., \& Collette, B. J. (1992). Magnetic anomalies in the Canary Basin and the Mesozoic evolution of the central North Atlantic. Marine Geophysical Researches, 14(1), 1-24.

Rosenbaum, G., Lister, G. S., \& Duboz, C. (2002). Relative motions of Africa, Iberia and Europe during Alpine orogeny. Tectonophysics, 359(1), 117-129.

Sahabi, M., 2004. Évolution cinématique triasico-jurassique de l'Atlantique central : implications sur l'évolution géodynmaique des marges homologues nord-ouest africaine et est américaine. Thèse de doctorat d'État Es-Science, Université Chouaïb Doukkali, El Jadida, 615p.

Sahabi, M., Aslanian, D., \& Olivet, J. L. (2004). Un nouveau point de départ pour l'histoire de l'Atlantique central. Comptes Rendus Geoscience, 336(12), 1041-1052.

Sallarès, V., Gailler, A., Gutscher, M. A., Graindorge, D., Bartolomé, R., Gràcia, E., ... \& Zitellini, N. (2011). Seismic evidence for the presence of Jurassic oceanic crust in the central Gulf of Cadiz (SW Iberian margin). Earth and Planetary Science Letters, 311(1), 112-123.

Sallarès, V., Gailler, A., Gutscher, M. A., Graindorge, D., Bartolomé, R., Gracia, E., Díaz, J., Dañobeitia, J. J. \& Zitellini, N. (2011). Seismic evidence for the presence of Jurassic oceanic crust in the central Gulf of Cadiz (SW Iberian margin). Earth and Planetary Science Letters, 311(1), 112-123.

Schettino, A., \& Turco, E. (2009). Breakup of Pangaea and plate kinematics of the central Atlantic and Atlas regions. Geophysical Journal International, 178(2), 1078-1097.

Schettino, A., \& Turco, E. (2011). Tectonic history of the western Tethys since the Late Triassic. Geological Society of America Bulletin, 123(1-2), 89-105.

Schmincke, H. U. (1982). Volcanic and chemical evolution of the Canary Islands. In Geology of the Northwest African continental margin (pp. 273-306). Springer Berlin Heidelberg. 
Sibuet, J.-C., Rouzo, S., Louden, K., 2011. PLAY FAIRWAY Analysis Offshore Nova Scotia Canada, Atlas.

Sibuet, J. C., Rouzo, S., \& Srivastava, S. (2012). Plate tectonic reconstructions and paleogeographic maps of the central and North Atlantic oceans 1, 21 Canadian Journal of Earth Sciences, 49(12), 1395-1415.

Smith, W. H., \& Sandwell, D. T. (1997). Global sea floor topography from satellite altimetry and ship depth soundings. Science, 277(5334), 1956-1962.

Spieker, K., Wölbern, I., Thomas, C., Harnafi, M., \& El Moudnib, L. (2014). Crustal and uppermantle structure beneath the western Atlas Mountains in SW Morocco derived from receiver functions. Geophysical Journal International, 198(3), 1474-1485.

Stampfli, G. M., \& Borel, G. D. (2002). A plate tectonic model for the Paleozoic and Mesozoic constrained by dynamic plate boundaries and restored synthetic oceanic isochrons. Earth and Planetary Science Letters, 196(1), 17-33.

Stampfli, G. M., Borel, G. D., Marchant, R., \& Mosar, J. (2002). Western Alps geological constraints on western Tethyan reconstructions. Journal of the Virtual Explorer, 8, 77-106.

Stockwell, J. W. (1999). The CWP/SU: seismic Un* x package. Computers \& Geosciences, 25(4), 415-419.

Tari, G., \& Molnar, J. (2005). Correlation of syn-rift structures between Morocco and Nova Scotia, Canada. In Transactions GCSSEPM Foundation, 25th Ann. Res. Conf (pp. 132-150).

Tari, G., \& Jabour, H. (2013). Salt tectonics along the Atlantic margin of Morocco. Geological Society, London, Special Publications, 369(1), 337-353.

Thiébot, E., Structure profonde et reactivation de la marge Nord-ouest-marocaine. Ph D. Thesis, Univ. of Brest, UMR6538, IUEM/UBO.

U.S. Department of Commerce, National Oceanic and Atmospheric Administration, National Geophysical Data Center, 2006. 2-minute Gridded Global Relief Data (ETOPO2v2) http://www.ngdc.noaa.gov/mgg/fliers/06mgg01.html

Van Avendonk, H. J., Holbrook, W. S., Nunes, G. T., Shillington, D. J., Tucholke, B. E., Louden, K. E., Larsen, H.-C., \& Hopper, J. R. (2006). Seismic velocity structure of the rifted margin of the eastern Grand Banks of Newfoundland, Canada. Journal of Geophysical Research: Solid Earth (1978-2012), 111(B11).

Verhoef, J., Roest, W. R., Macnab, R., \& Arkani-Hamed, J. (1996). Magnetic anomalies of the Arctic and North Atlantic oceans and adjacent land areas (Vol. 3125). Dartmouth NS: Geological Survey of Canada.

Vogt, P. R., 1973. Early events in the opening of the North Atlantic. In Tarling, D. H. and Runcorn, S. K. (Eds.), In: implications of continental drift to the earth sciences: London (Academic Press), v. 2, p. 693-712. 
Watts, A. B. (1994). Crustal structure, gravity anomalies and flexure of the lithosphere in the vicinity of the Canary Islands. Geophysical Journal International, 119(2), 648-666.

Wegener, A. (1912). Die Entstehung der Kontinente. Geologische Rundschau, 3(4), 276-292.

Weigel, W., Wissmann, G., \& Goldflam, P. (1982). Deep seismic structure (Mauritania and central Morocco). In Geology of the northwest african continental margin (pp. 132-159). Springer Berlin Heidelberg.

Wessel, P., \& Smith, W. H. (1995). The Generic Mapping Tools, GMT, Version 3: Technical Reference and Cookbook. School of Ocean and Earth Science and Technology, University of Hawaii at Manoa.

White, R. S., McKenzie, D., \& O'Nions, R. K. (1992). Oceanic crustal thickness from seismic measurements and rare earth element inversions. Journal of Geophysical Research: Solid Earth (1978-2012), 97(B13), 19683-19715.

White, R. S., Smith, L. K., Roberts, A. W., Christie, P. A. F., Kusznir, N. J., Roberts, A. M., ... \& Tymms, V. J. (2008). Lower-crustal intrusion on the North Atlantic continental margin. Nature, 452(7186), 460-464.

Wu, Y., Louden, K. E., Funck, T., Jackson, H. R., \& Dehler, S. A. (2006). Crustal structure of the central Nova Scotia margin off Eastern Canada. Geophysical Journal International, 166(2), 878906.

Ye, S., Canales, J. P., Rihm, R., Danobeitia, J. J., \& Gallart, J. (1999). A crustal transect through the northern and northeastern part of the volcanic edifice of Gran Canaria, Canary Islands. Journal of Geodynamics, 28(1), 3-26. 
Figure 1: Seafloor bathymetry and topography from the ETOPO data set (US Department of commerce). Location of the wide-angle seismic profiles acquired during the SISMAR, DAKHLA and MIRROR cruises. The WACMA magnetic anomaly which marks the initial opening of the ocean is shown by orange and red outlines depending on their amplitude, with red representing the higher amplitudes.

Figure 2: (A) Free-air gravity anomaly of the central Atlantic from satellite measurements.

Magnetic anomalies ECMA, BSMA and WACMA are shown in orange and red. Location of wideangle seismic surveys used in this study are marked by bold blacklines and fracture zones by thin black lines.Frame shows location of blow-up. (B) Gravity anomaly of the central Atlantic from satellite measurements. Blue lines show margin segments from Hinz et al., 1982 and yellow lines segment boundaries used in this study. AFZ = Atlantis Fracture Zone, GC = Gulf of Cadiz, $S B=$ North African Salt Basin (Bonvalot et al., 2012). Segments from earlier work are annotated by blue lines numbered 1-5 (Hinz et al., 1982)

Figure 3: 2D-Model of the conjugate margins of Morocco and Nova Scotia at a pre-rupture stage (based on the SISMAR and SMART 1 profiles see location on Fig. 2). The margin structure is based on seismic reflection and refraction data from the SISMAR and Smart cruises. Note the asymmetry of the margins at the continent-ocean boundary (COB). Black squares are homologous points along the large detachment fault, whose latest active part were landward dipping reflectors (LDR). (from Maillard et al., 2006).

Figure 4: Late Triassic syn-rift reconstruction of the Moroccan and Nova Scotian margins. The fault bounded basement high of the Tafelney Plateau is interpreted to be a high relief accomodation zone separating major fault domains with different polarity of normal faulting (from Tary and Molnar, 2005). In the yellow area the American margin corresponds to the upper plate margin and in the orange area to the lower plate margin. HRAZ: High relief accomodation zone

Figure 5: Sketch showing the two eastward rift-ridge jumps at 190 Ma explaining the presence of salt features westward of WACMA, and the eastward shift at 177 Ma explaining the absence of serpentinized peridotite on the Moroccan side, respectively (from Sibuet et al., 2012). ECMA : East Coast Magnetic Anomaly, WACMA: West African Magnetic Anomaly, BSMA: Blake Spur Magnetic Anomaly; IB: Iberia, NA: North America.

Figure 6: Variation of volcanism along the Nova Scotia-Morocco conjugates: (a) the conceptualized crustal structure across the NE segment; $(b)$ the crustal structure across the central segment; and (c) the crustal structure across the SW segment. COB: continent ocean boundary, FB: faulted blocks, SDR: Seaward dipping reflector (From Louden et al., 2012).

Figure 7: Seafloor bathymetry and topography from the ETOPO data set (US Department of commerce). Position of wide-angle and reflection seismic profiles in the southern segment. Black lines represent reflection seismic profiles of the DAKHLA cruise, blue lines reflection seismic profiles from BGR cruises, blue triangles and inverted triangles are positions of sonobuoys from existing compilations (R/V Atlantis II cruises 67 and 75 : URL http://www.geomapapp.org ; Weigel et al., 1982). Yellow lines mark segment limits and orange shaded polygones the position 
of the WACMA.

Figure 8: Magnetic anomaly of the DAKHLA cruise study region shown together with bathymetric contours from satellite altimetry and location of the seismic profiles (black lines) (Maus et al., 2009; Sandwell and Smith, 1997). Ocean bottom instrument locations are marked by circles and landstation locations by inverted triangles (Klingelhoefer et al., 2009).

Figure 9: (A)-(D) Final velocity models for the all four profiles from the DAKHLA cruise including the model boundaries used during inversion (solid lines) and isovelocity contours every 0.25 $\mathrm{km} / \mathrm{s}$. Ocean bottom seismometers $(O B S)$ locations are indicated by red circles and landstation locations by red inverted triangles. Vertical exaggeration 1:4. (E) Location map of the seven wide-angle seismic profiles of the DAKHLA cruise. Orange square marks unthinned continental crustal domain, yellow square domain of crustal thinning, violet square the ocean-continent transition zone and green square the oceanic domain.

Figure 10: Seafloor bathymetry and topography from the ETOPO data set (US Department of commerce). Position of wide-angle and reflection seismic profiles in the central segment. Black lines represent reflection seismic profiles of the MIRROR cruise, blue lines reflection seismic profiles from BGR cruises, blue triangles and inverted triangles are positions of sonobuoys from existing compilations (R/V Atlantis II cruises 67 and 75 : URL http://www.geomapapp.org ; Holik et al., 1991). Yellow lines mark segment limits and orange shaded regions the position of the WACMA. Grey polygon marks the Tafelney Plateau.

Figure 11:Lower crustal velocities in the central segment from sonobuoy and OBS deployments (Holik et al., 1991; Biari et al., 2015). For the sonobuy data this velocity corresponds to the constant layer velocity and for the OBS data to the mean velocity of the lower crustal layer. Background contoured bathymetry from satellite altimetry (Smith and Sandwell, 1997). Positions of sonobuoys are marked by inverted triangles (Holik et al., 1991) and OBS (Biari et al., 2015) by black circles. Blue lines mark position of multi-channel seismic (MCS) profiles, red line the extent of the basement bulge from Holik et al. (1991) and red dots the position over time of the Canary Island Hotspot (Carracedo et al., 1998).

Figure 12: Magnetic anomaly of the MIRROR cruise study region with bathymetric contours from satellite altymetry overlain and location of the seismic profiles (black lines) (Maus et al., 2009; Sandwell and Smith, 1997). Location of ocean bottom instruments and landstations are marked by circles and triangles, respectively.

Figure 13: (A)-(G) Final velocity models for the profiles of the MIRROR survey including the layer boundaries used during modelling (solid lines) and isovelocity contours every $0.25 \mathrm{~km} / \mathrm{s}$. OBS locations are indicated by red circles and landstation locations by red inverted triangles. Vertical exaggeration 1:4. (H) Location map of the seven wide-angle seismic profiles of the MIRROR cruise (after Biari et al., 2015). Orange square marks unthinned continental crustal domain, yellow square domain of crustal thinning, violet square the ocean-continent transition zone and green square the oceanic domain.

Figure 14: Seafloor bathymetry and topography from the ETOPO data set (US Department of 
commerce). Position of wide-angle and reflection seismic profiles in this segment. Black lines represent reflection seismic profiles of the SISMAR cruise, blue lines reflection seismic profiles from BGR cruises, blue triangles and inverted triangles are positions of sonobuoys from existing compilations (R/V Atlantis II cruises 67 and 75 : URL http://www.geomapapp.org ; Weigel et al., 1982). Yellow lines mark segment limits, red shaded regions the location of salt diapirs (Sahabi et al., 2004) and orange shaded regions the position of the WACMA.

Figure 15: Magnetic anomaly of the DAKHLA cruise study region with bathymetric contours from satellite altimetry overlain (Maus et al., 2009; Sandwell and Smith, 1997) and location of the seismic profiles (black lines). Ocean bottom instrument locations are marked by circles and landstation locations by inverted triangles. Dashed redlines outline the extend of theWACMA.

Figure 16: (A)-(D) Final velocity models for the all four profiles of the SISMAR cruise including the model boundaries used during inversion (solid lines) and isovelocity contours every $0.25 \mathrm{~km} / \mathrm{s}$. OBS locations are indicated by red circles and landstation locations by red inverted triangles. Vertical ex. 1:4. Orange square marks unthinned continental crustal domain, yellow square domain of crustal thinning, violet square the ocean-continent transition zone and green square the oceanic domain. (E) Location map of the 4 wide-angle seismic profiles of the SISMAR cruise. Orange polygones mark the extend of the WACMA.

Figure 17: (A) Detailed reconstruction showing segmentation of the western Tethyan oceanic lithosphere formed at an oblique spreading center (from Frizon de Lamotte et al., 2011). (B) 3-D block diagram of the lithospheric structure of the Iberia-Maghreb region, with shaded hill relief at the surface. The primary plate and block boundaries, expressed by crustal seismicity and the GPS velocity field are shown as a thick dashed lines, the active Rif-Betic front as filled red teeth and the deformation front of the accretionary wedge by green teeth. The asymmetric shape of the oceanic slab at depth is imaged by seismic tomography (from Gutscher et al., 2012) .

Figure 18: Seafloor bathymetry and topography from the ETOPO data set (US Department of commerce). Position of wide-angle and reflection seismic profiles in the Gulf of Cadiz. Black lines represent reflection seismic profiles of the SISMAR N cruise, blue lines reflection seismic profiles from BGR cruises, blue triangles and inverted triangles are positions of sonobuoys ( $R / V$ Atlantis II cruises 67 and 75 : URL http://www.geomapapp.org ; Weigel et al., 1982).White broken line marks the extent of the deformation front of the accretionary wedge.

Figure 19: (A) Magnetic anomaly along profile SISMAR 13 (B) Final velocity model for profile SISMAR Nord including the model boundaries used during inversion (solid lines) and isovelocity contours every $0.25 \mathrm{~km} / \mathrm{s}$. OBS locations are indicated by red circles and landstation locations by red inverted triangles. Areas unconstrained by raytracing modelling are shaded. Orange square marks unthinned continental crustal domain, yellow square domain of crustal thinning, violet square the ocean-continent transition zone and green square the oceanic domain. $(C)$ Mean velocity-depth profile in the green shaded area. Red line represents mean vz-profile from the green shaded region, Grey outline represents typical oceanic crust (White et al., 1992) and grey line velocities of thinned continental crust (Christensen and Mooney, 1995) (D) Mean velocity-depth profile in the violet shaded area $(E)$ Mean velocity-depth profile in the yellow 
shaded area $(F)$ Mean velocity-depth profile in the orange shaded area.

Figure 20: (A) Wide-angle seismic model of profile SISMAR 4 (B) Wide-angle seismic model of profile MIRROR 01 (C) Wide-angle seismic model of profile DAKHLA Nord (D) Location map of the wide-angle seismic profiles.

Figure 21: (A) Wide-angle seismic model of profile SISMAR 4 (B) Wide-angle seismic model of profile MIRROR 01 (C) Wide-angle seismic model of profile DAKHLA Nord (D) Location map of the wide-angle seismic profiles.

Figure 22: Location map of the existing land surveys. Red dots mark landstation from Spieker et al. (2014) and blue line wide-angle seismic profiles from Markris et al. (1985). WACMA is marked by orange and red outlines and Tafelney plateau by grey outlines. Position of the MIRROR profiles are represented by black lines and landstations by black inverted triangles. Red dots mark the position over time of the Canary Island Hotspot (Carracedo et al., 1998).

Figure 23: Velocity-depth profiles underneath the basement in the OCT. Red line-MIRROR, Green line - SISMAR, Blue line -DAKHLA. Grey lines - thinned continental crust from Christensen and Mooney 1995; blue underlay :oceanic crust from White et al. 1992, yellow underlay exhumed and serpentinised upper mantle in the OCT from Dean et al., 2000 and Van Avendonk et al., 2006.

Figure 24: Magnetic anomaly in the study region (Maus et al., 2009). WACMA is marked by red transparent area, M25 and MO by red lines. High velocity zones of Holik et al., 1991 and Klingelhoefer et al., 2010 are marked by orange transparent region. Basement bulge of Patriat et al., 2006 by blue broken line and zone of smooth basement by blue line. Zone of smooth basement from Ranero and Banda 1997 is shown by grey transparent area. Seismic lines are marked by black lines.

Figure 25: Examples of volcanic products identified in the study region. (A) Seamounts in the region of the postulated Canary Island hotspot track (Carracedo et al.,1998), with adjacent highamplitude reflections which may represent magmatic sills. (B) Seaward and landward dipping reflections located on the S1 magnetic anomaly (Roeser et al., 2002). (C) Volcanic ash layer on basement high proposed to result from the passage of the Canary Island Hotspot (Holik et al., 1991). (D) Location map of the seismic profiles shown in $(A)-(C)$. Red dots mark the position over time of the Canary Island Hotspot (Carracedo et al., 1998).

Figure 26: Plate kinematic reconstruction of the central Atlantic at M25 (156.5 Ma) after Sahabi et al., 2004. Wide angle seismic profiles are marked by red lines and magnetic anomalies ECMA, WACMA and BSMA by orange and red outlines.

Figure 27: (A) Wide-angle seismic model of profile SISMAR 4 (Contrucci et al., 2004) (B) Wideangle seismic model of profile Smart 1 (Funck et al., 2004) (C) Wide-angle seismic model of profile MIRROR 01 (Biari et al., 2015) (D) Wide-angle seismic model of profile Smart 2 (Wu et al., 2006) (E) Wide-angle seismic model of profile Lase (Diebold and Stoffa, 1988) (F) Wide-angle seismic model of profile DAKHLA Nord (Klingelhoefer et al., 2009).

Figure 28: Comparison between the SMART 1 and MIRROR 1 conjugate wide-angle seismic models. $(A)$ and $(B)$ magnetic anomaly along seismic profiles $(C)$ and $(D)$ Wide-angle seismic 
models. Regions of different crustal nature are underlain (Orange - unthinned continental crust, Yellow - thinned continental crust, pale yellow - very thin continental crust overlying serpentinised upper mantle, violet-OCT, green-oceanic crust) $(E)$ to $(M)$ Velocity-depth-relationships extracted from the seismic models at regions according to their background colour.

Figure 29: Comparison between the SMART 1 and MIRROR 1 reflection seismic data of the oceanic domain. (A) Profile BGR89-12, coincident with the oceanic part of the SMART profile (B) Oceanic part of the MIRROR 01 profile $(C)$ Bathymetric data with a plate cinematic reconstruction at Anomaly M25 (156 Ma). Magnetic anomalies ECMA and WACMA are marked by orange and red outlines and parts of the profiles shown in $(A)$ and $(B)$ are marked by red lines.TWT: two-way travel-time. 
Figure 1

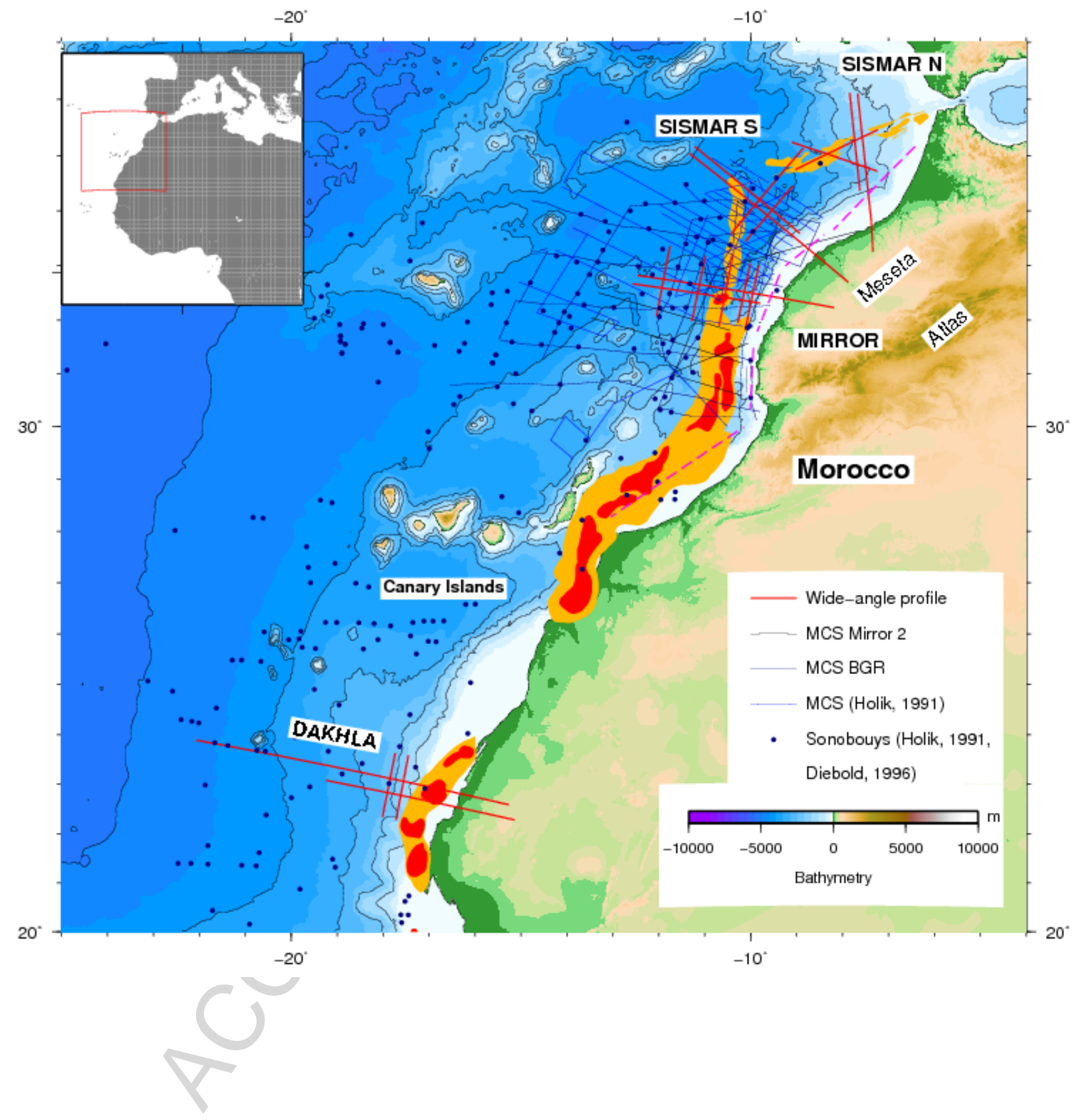


Figure 2
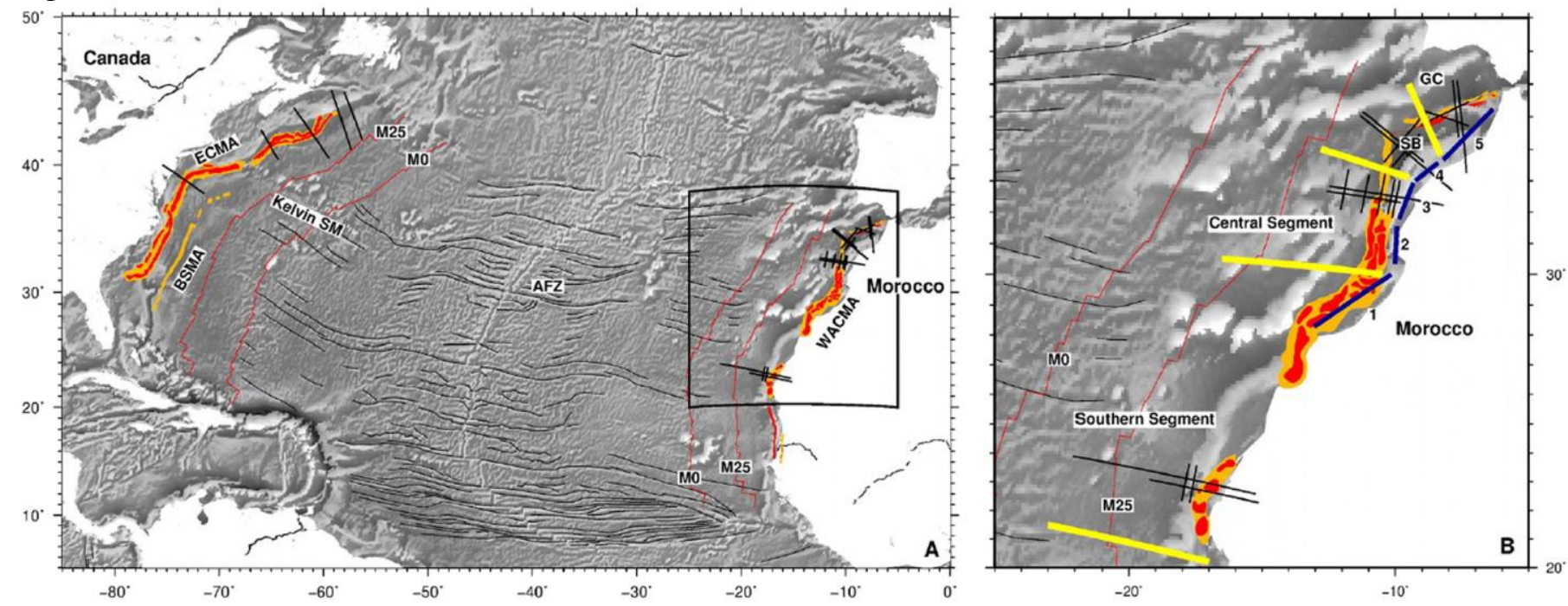
Figure 3

Canadian Conjugate Margin

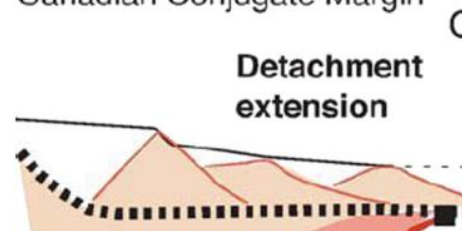

\section{$\mathrm{COB} \quad$ Lithospheric $\mathrm{COB}$}

:Detachment Rifting extension

Moroccan Margin

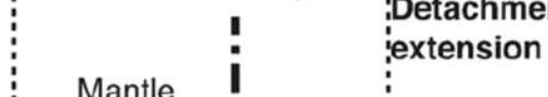

Upper crust

exhantle extension

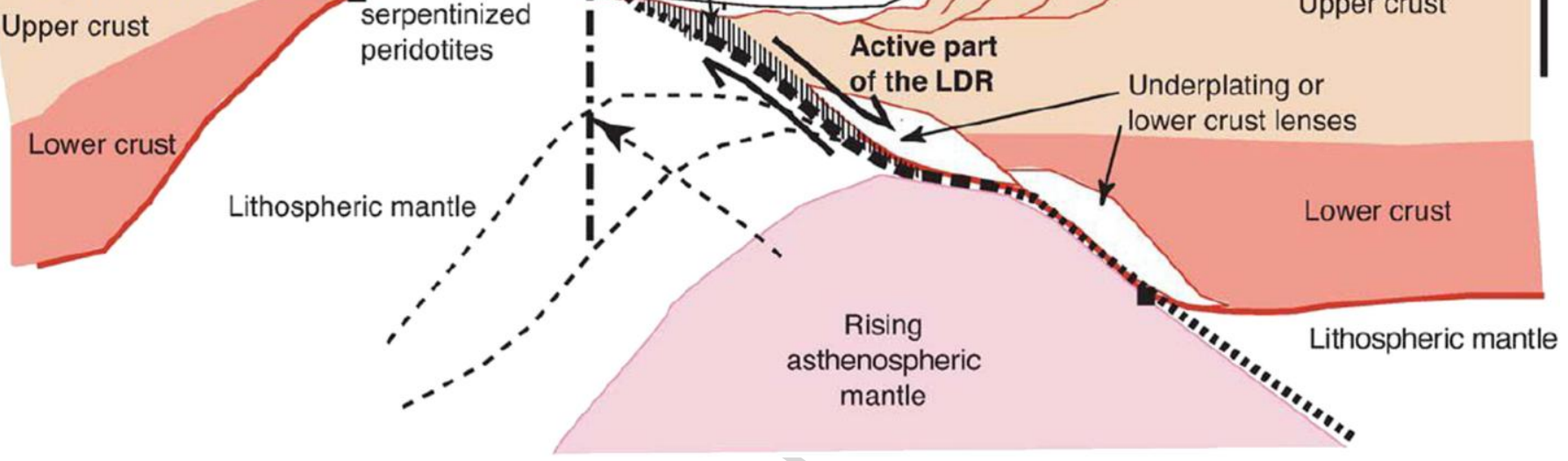


Figure 4

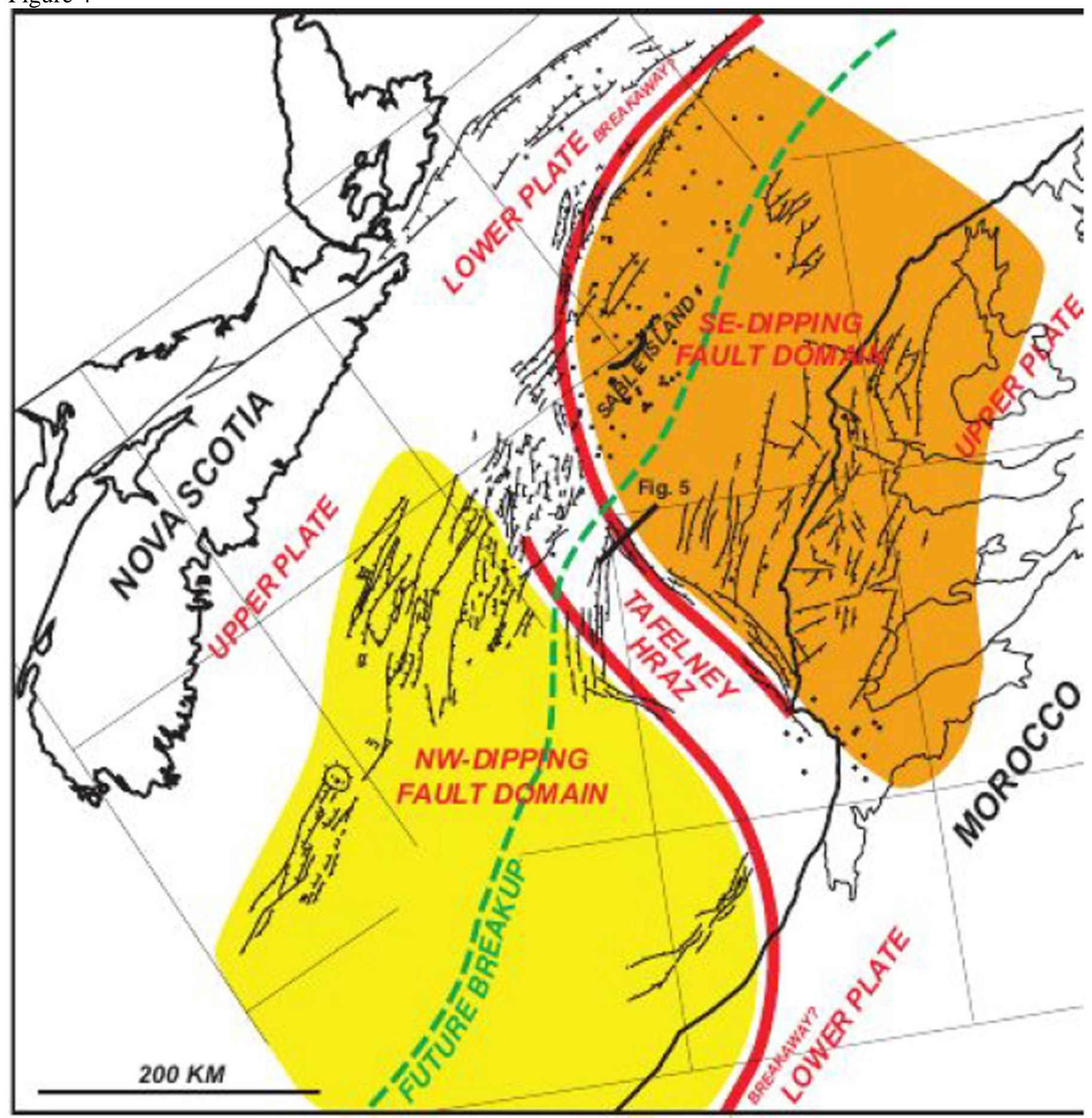


Figure 5

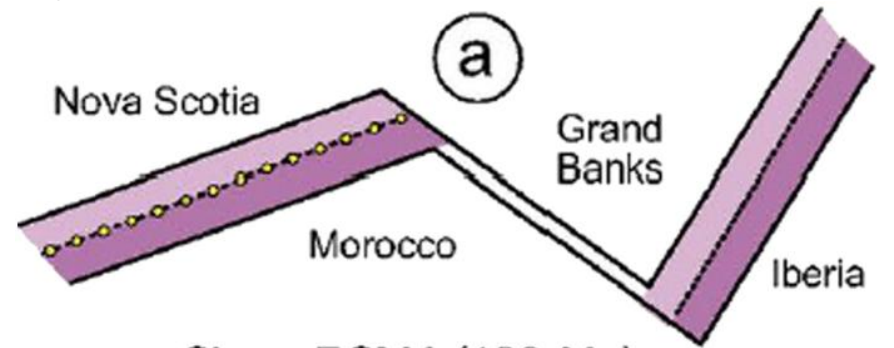

Chron ECMA (190 Ma) Formation of thinned continental crust and deposition of salt during rifting from 203 to $190 \mathrm{Ma}$ (IB is attached to MES)

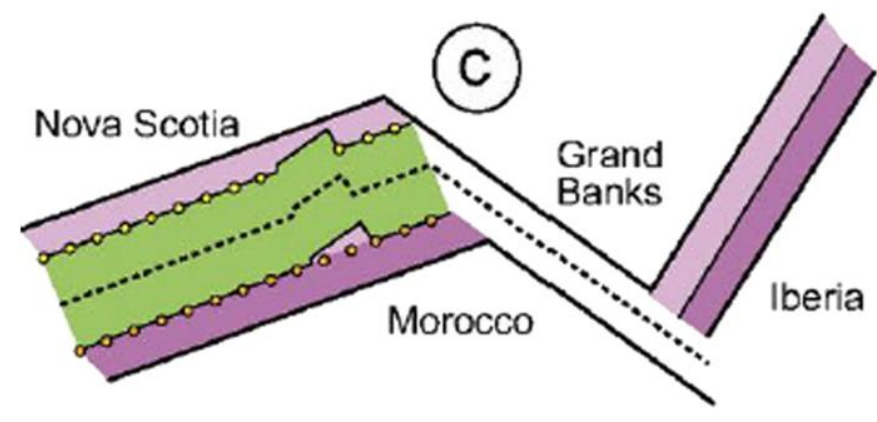

$177 \mathrm{Ma}$

Mantle exhumation from 190 to $177 \mathrm{Ma}$ (IB is attached to NA)

Salt deposited on the Nova Scotia margin Salt deposited on the Moroccan margin

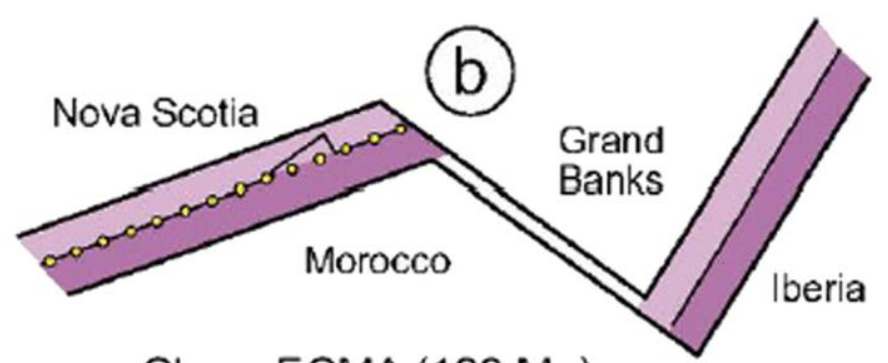

Chron ECMA (190 Ma)

Ridge jump at $190 \mathrm{Ma}$

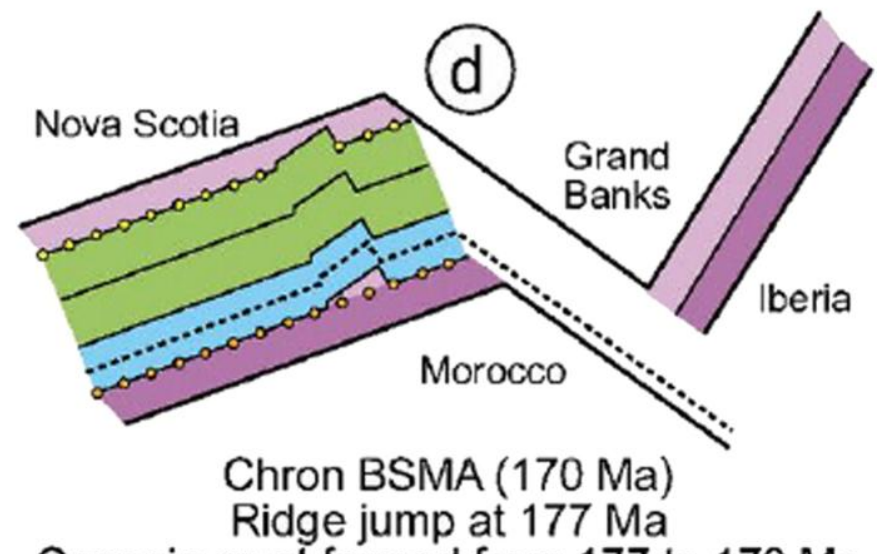

Oceanic crust formed from 177 to $170 \mathrm{Ma}$

(IB is attached to NA)

Serpentinized mantle

Oceanic crust
Rift axis

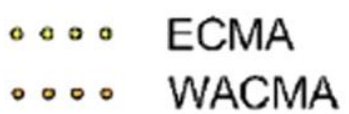


Figure 6

(a)

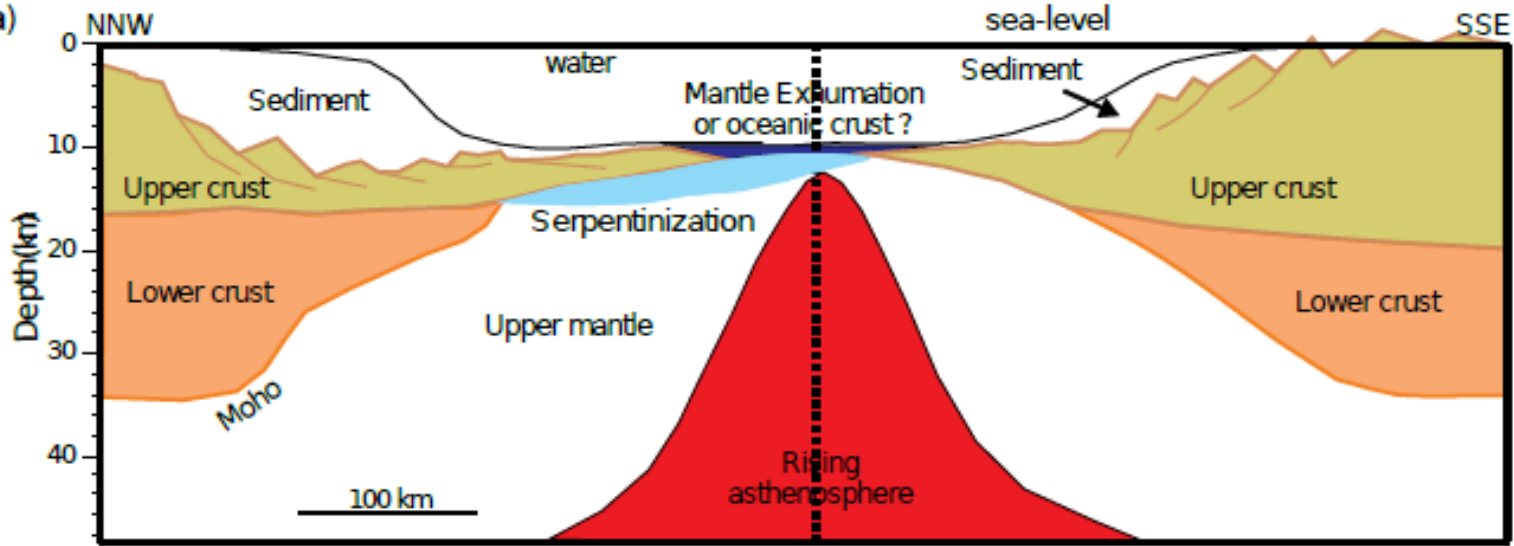

(b) NNW $\quad$ Sea-level SSE

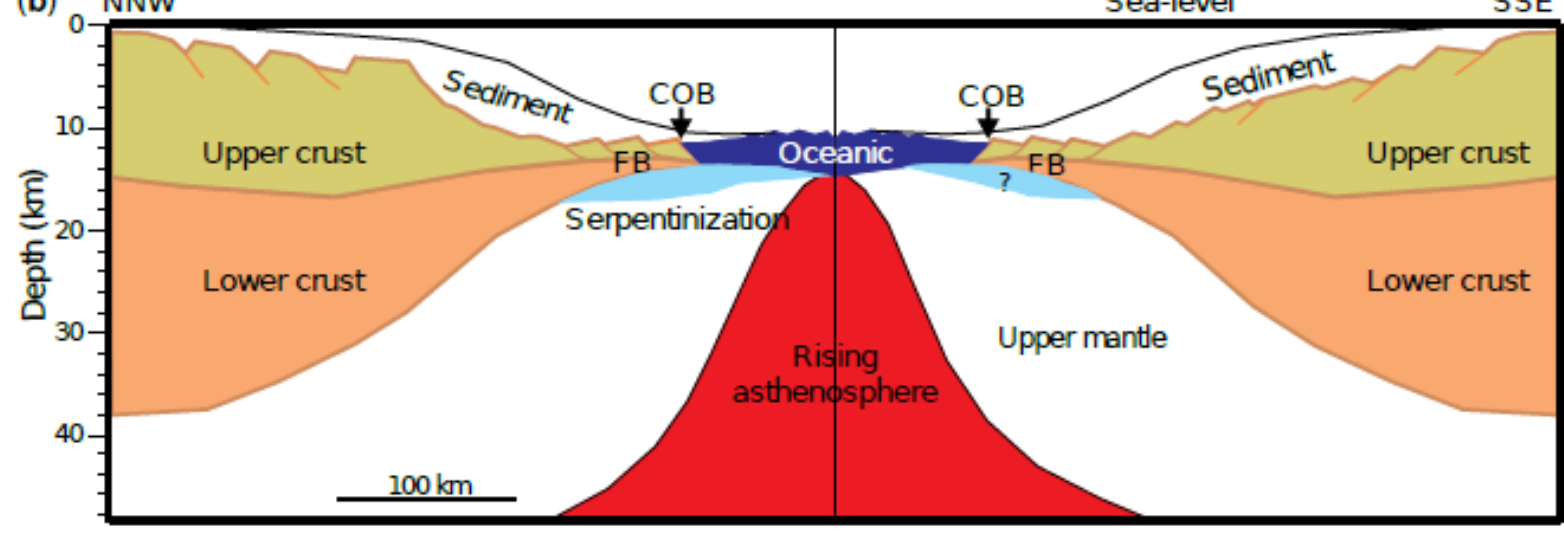

(c) NNW $\quad$ Sea-level SSE

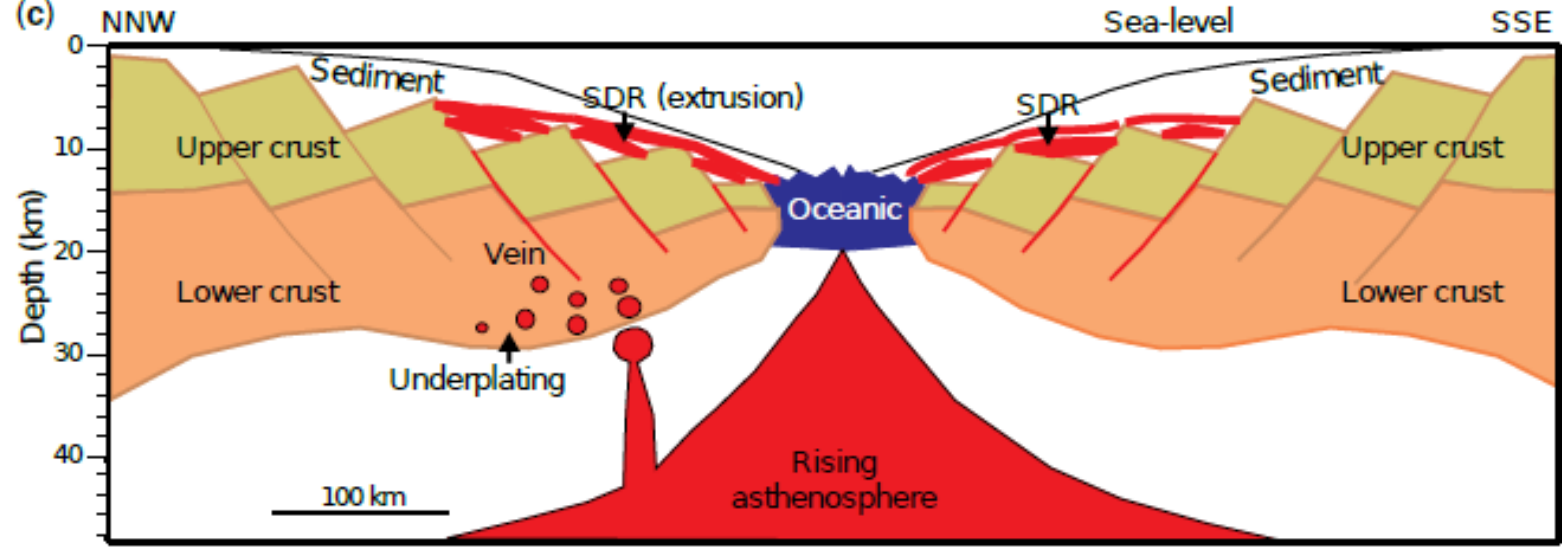


Figure 7

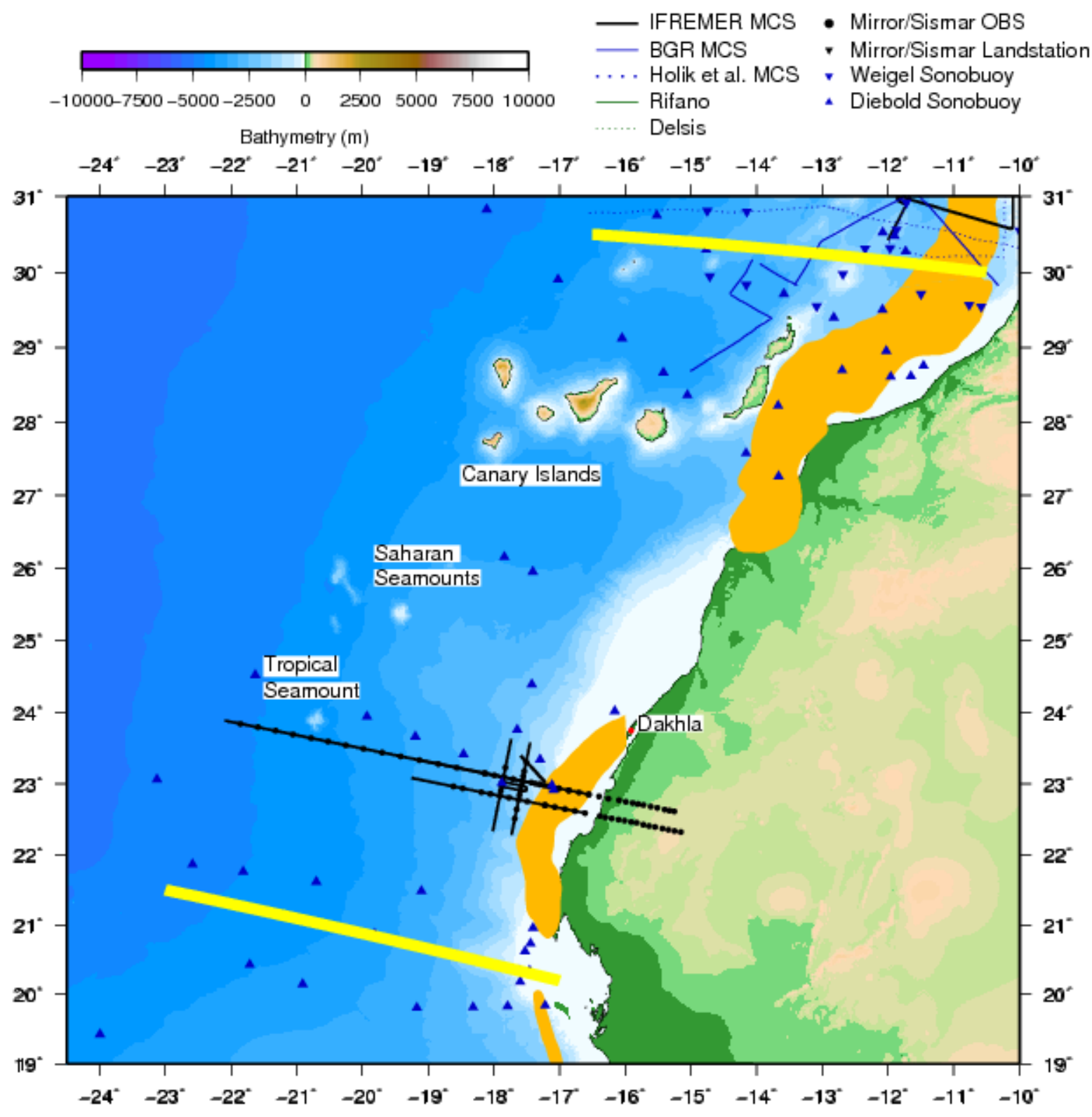




\section{ACCEPTED MANUSCRIPT}

Figure 8

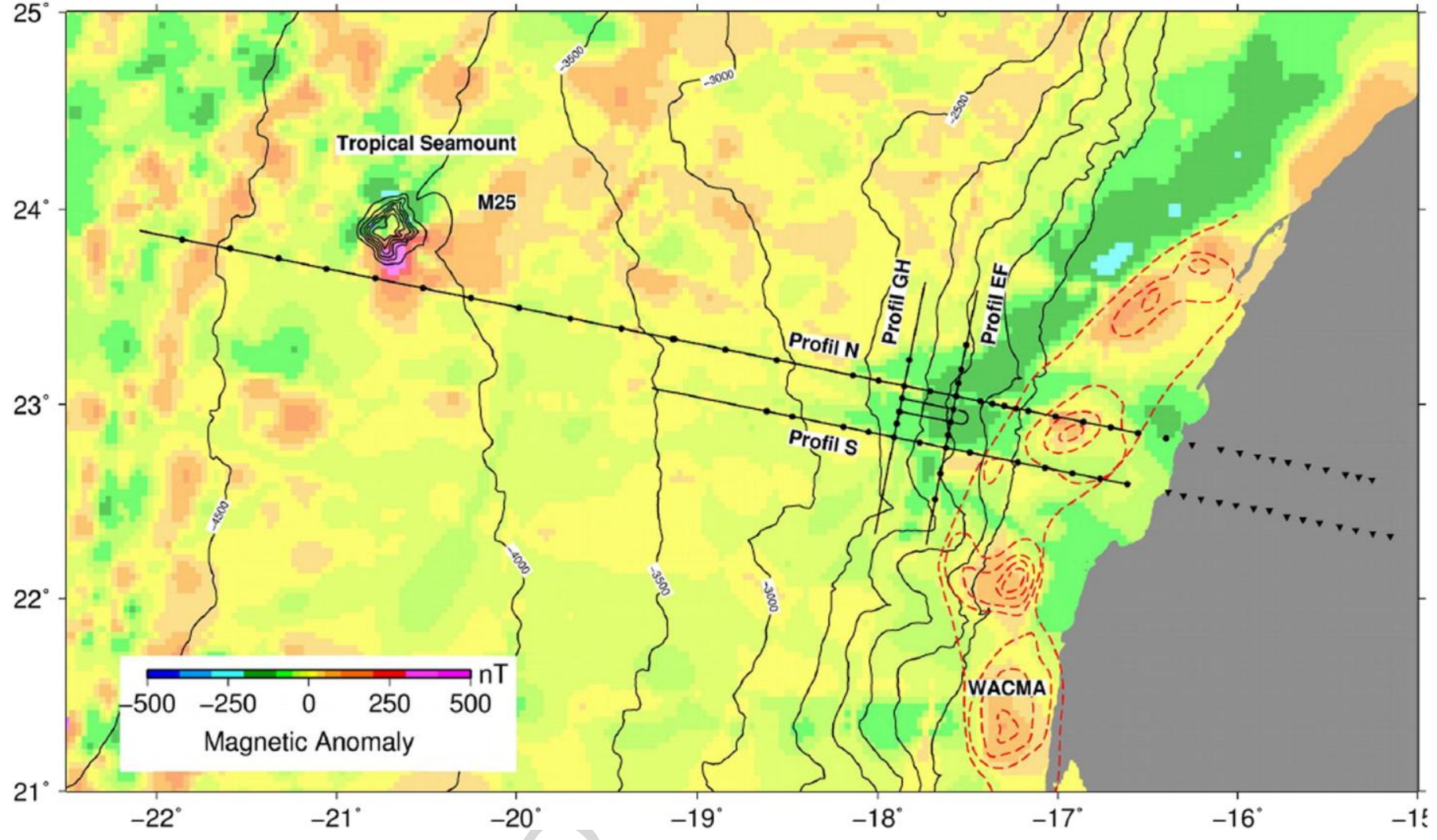


Figure 9
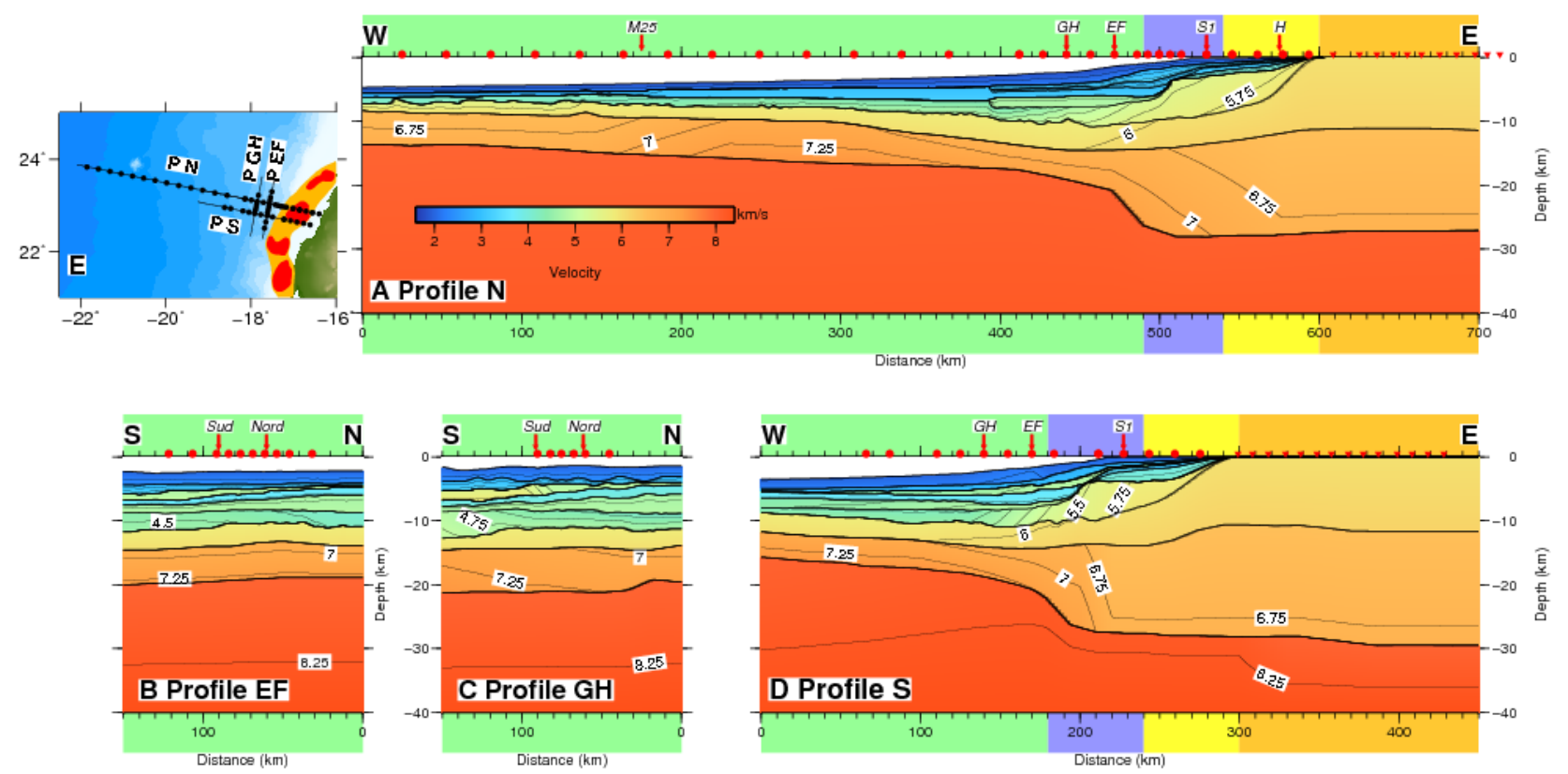
Figure 10

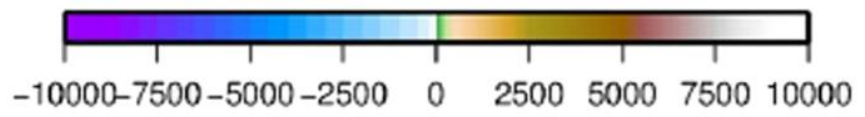

Bathymetry (m)

\section{- IFREMER MCS - Mirror/Sismar OBS \\ _ BGR MCS \\ ... Holik et al. MCS r Holik Sonobuoy \\ 4 Diebold Sonobuoy}

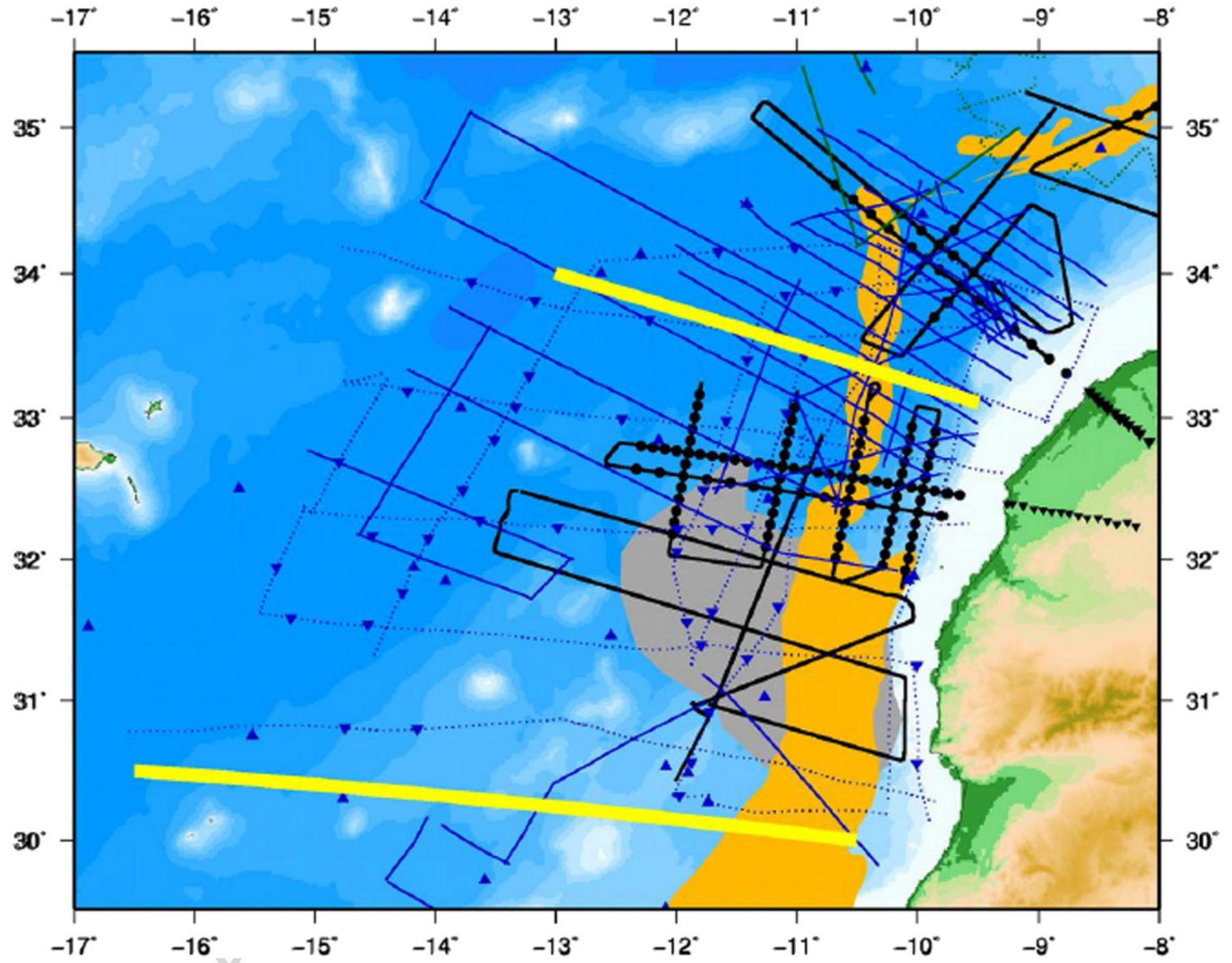


Figure 11

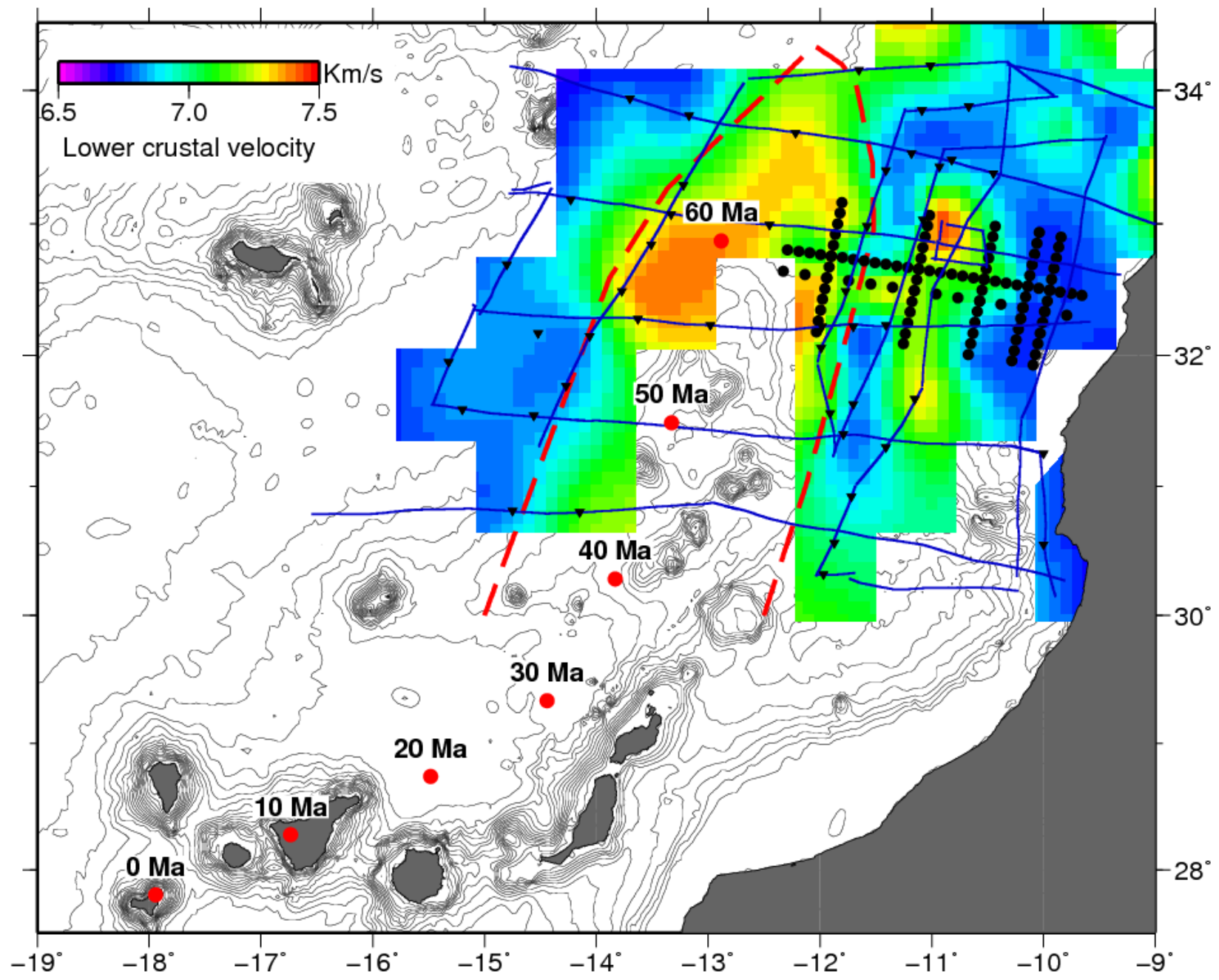


Figure 12

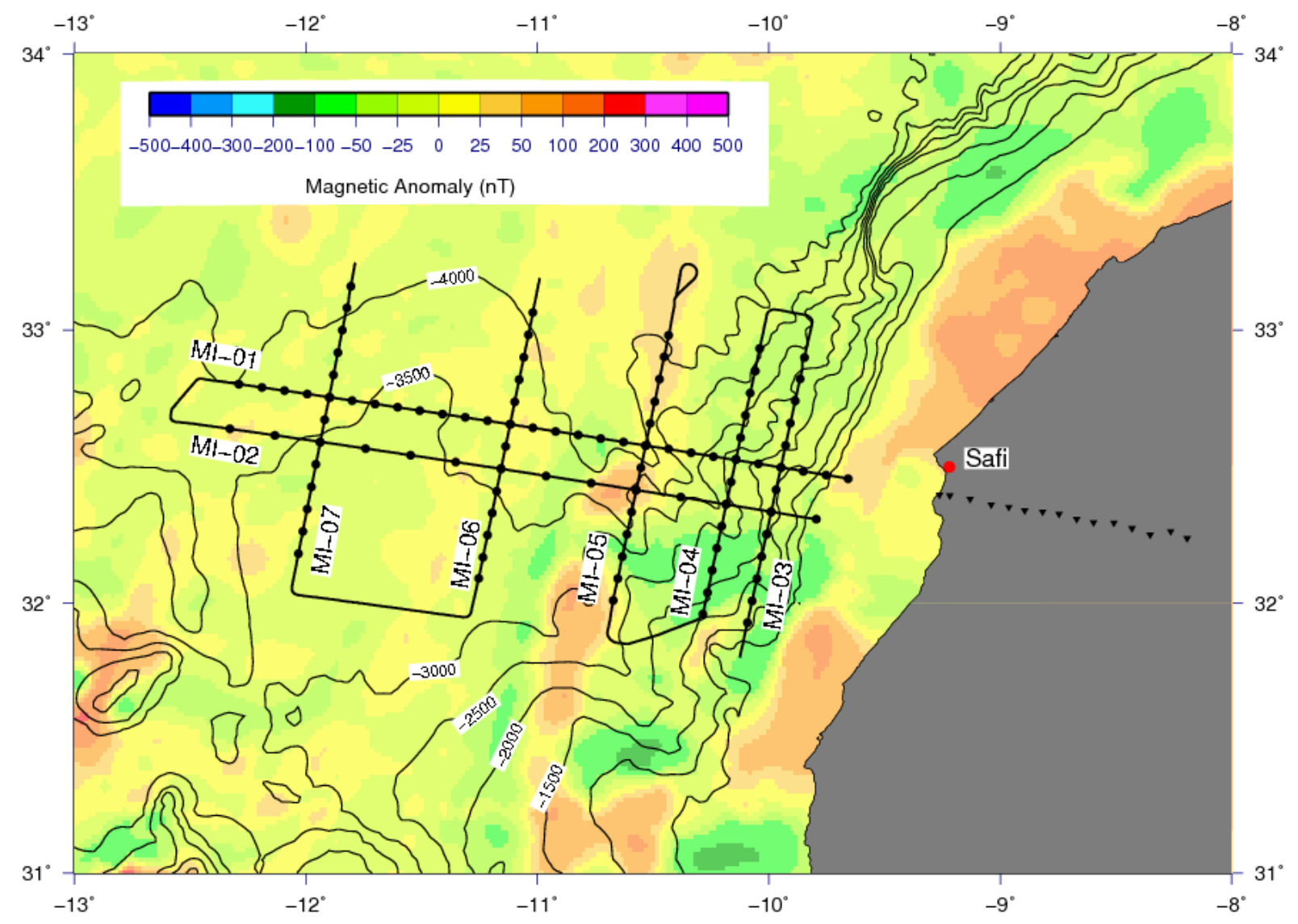


Figure 13
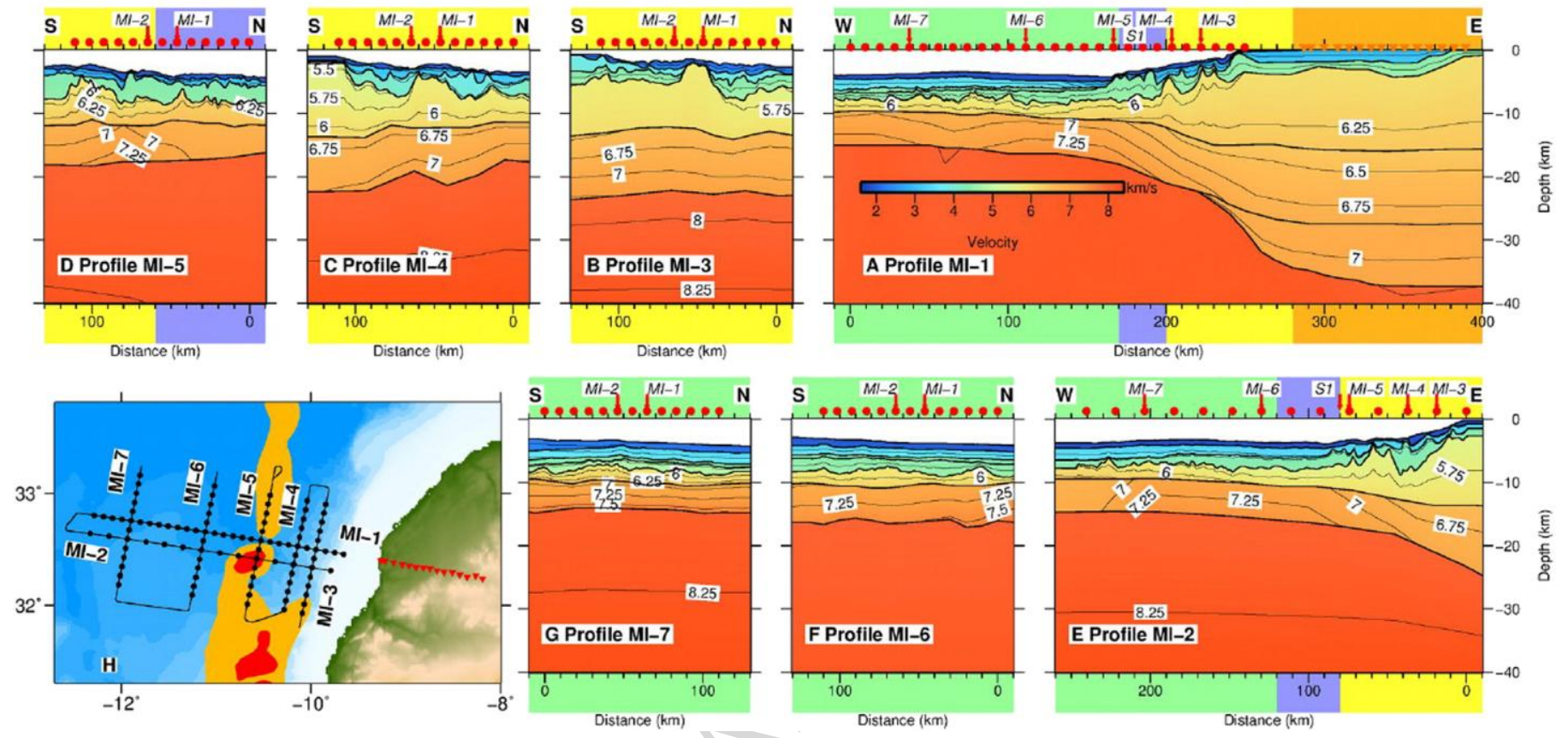
Figure 14

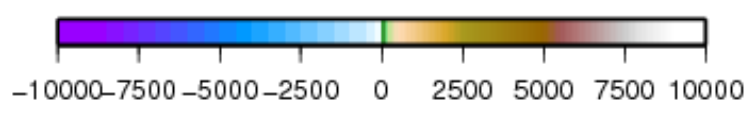

Bathymetry (m)
— IFREMER MCS BGR MCS Holik et al. MCS
Rifano Delsis
- Mirror/Sismar OBS
- Mirror/Sismar Landstation
- Holik Sonobuoy
- Diebold Sonobuoy

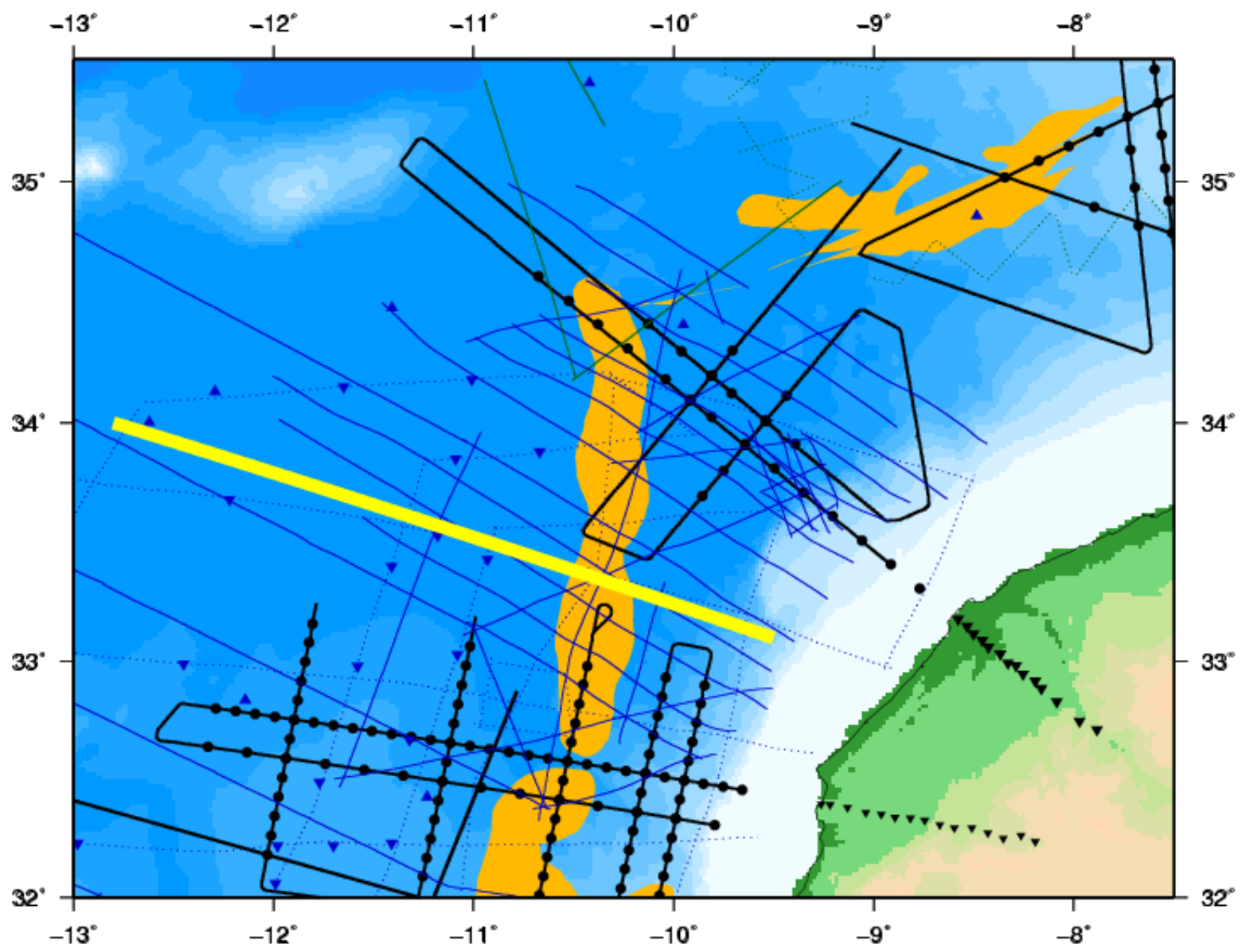


Figure 15

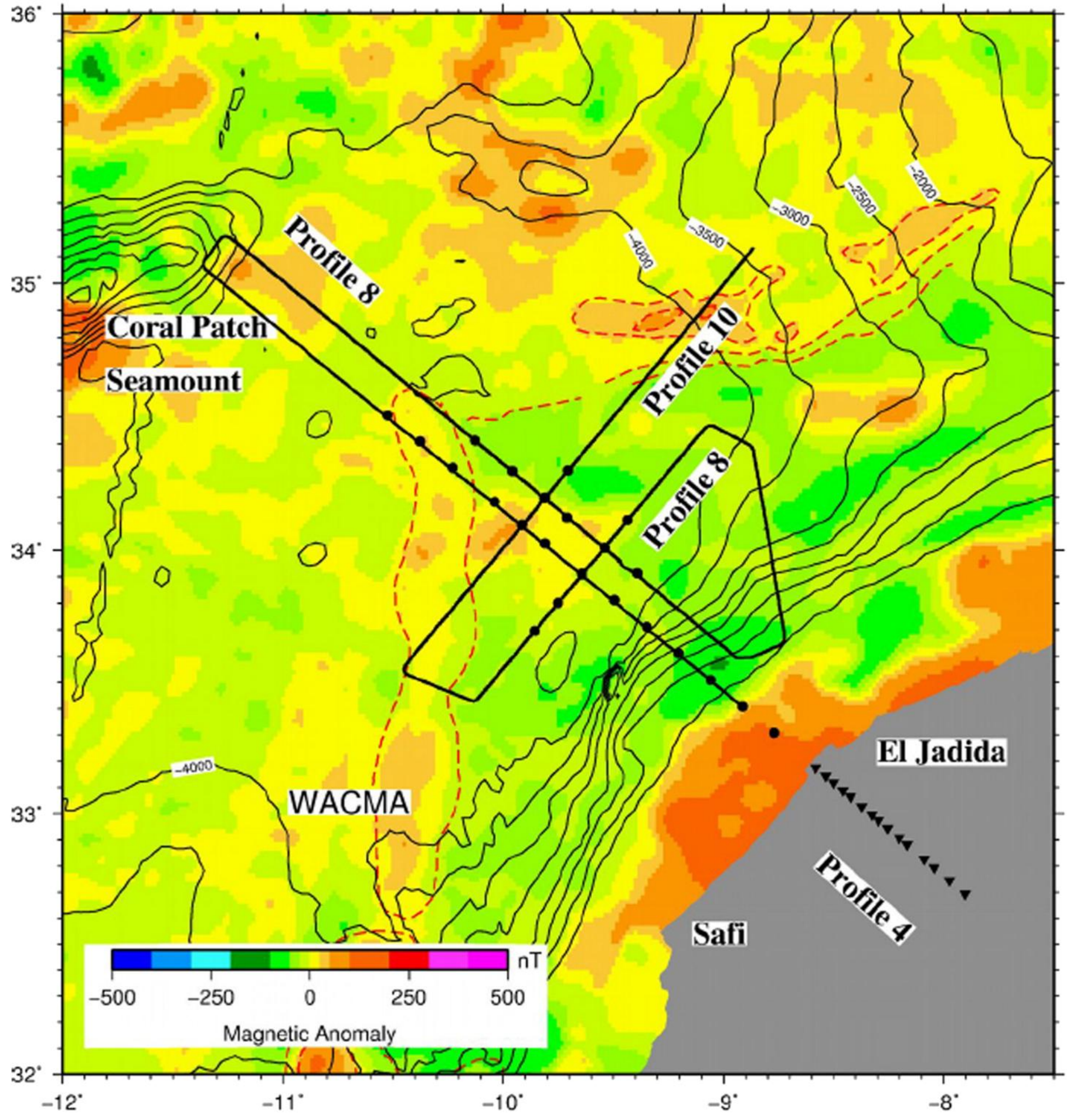


Figure 16
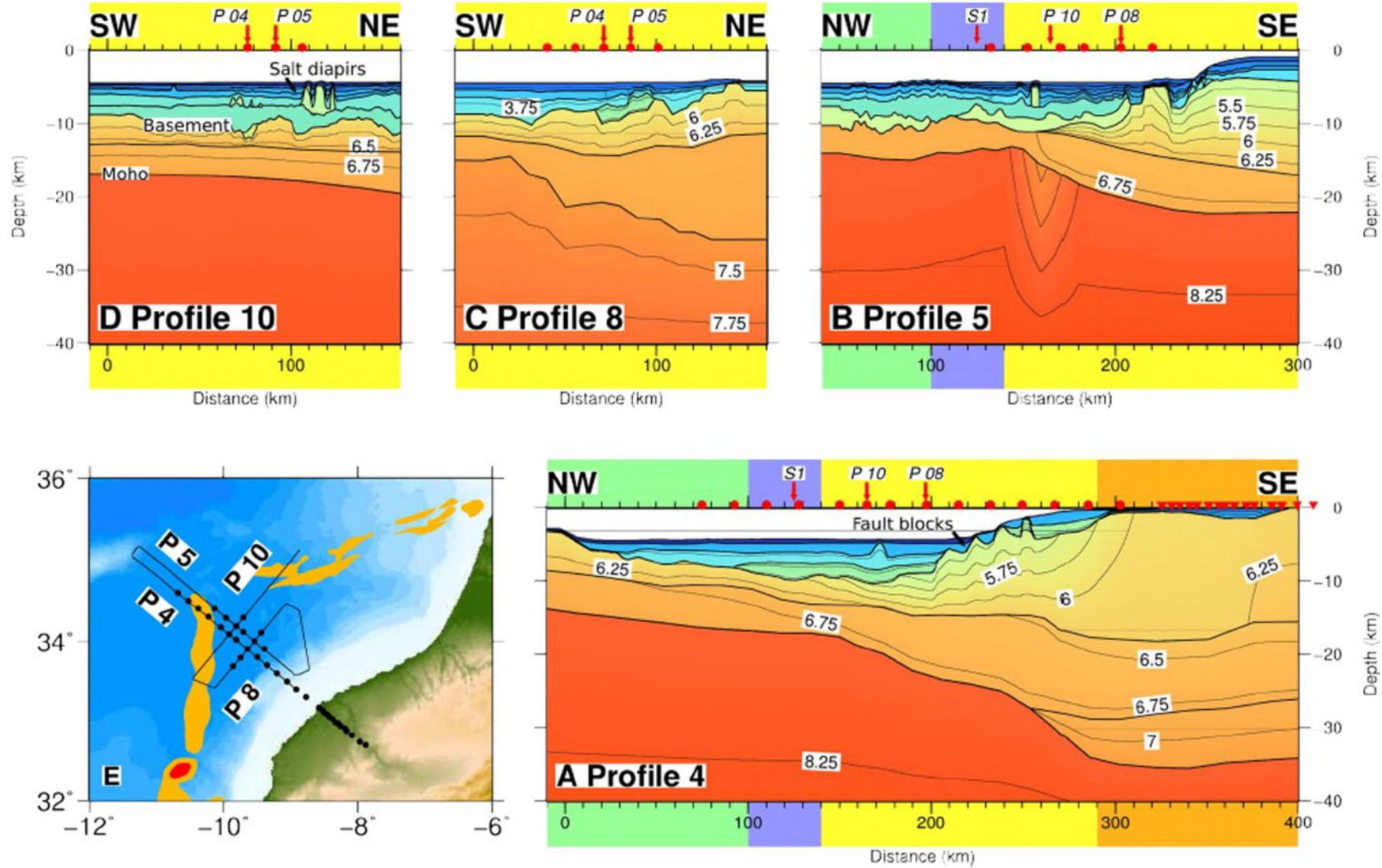


\section{ACCEPTED MANUSCRIPT}

Figure 17
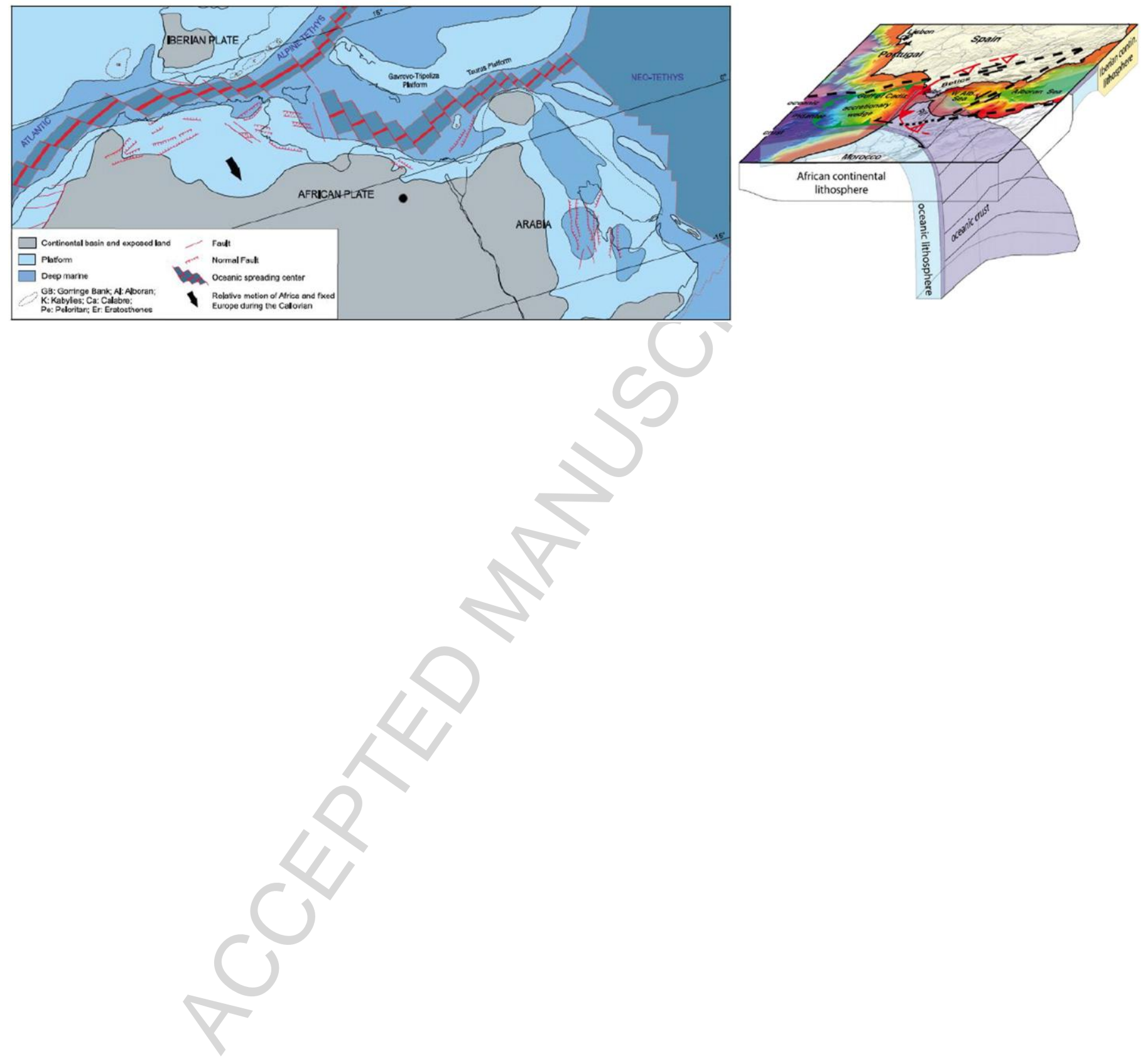
Figure 18

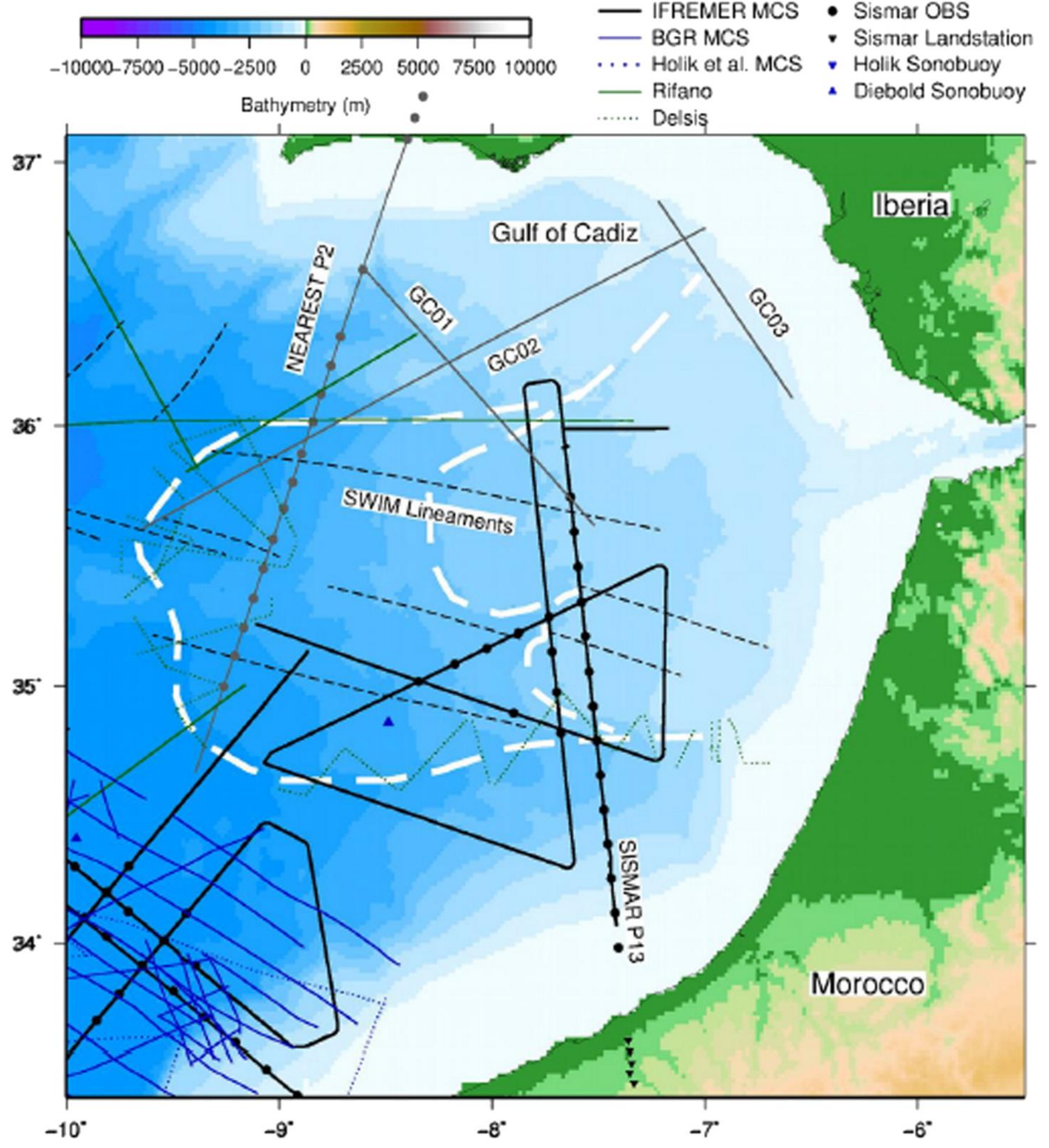


Figure 19
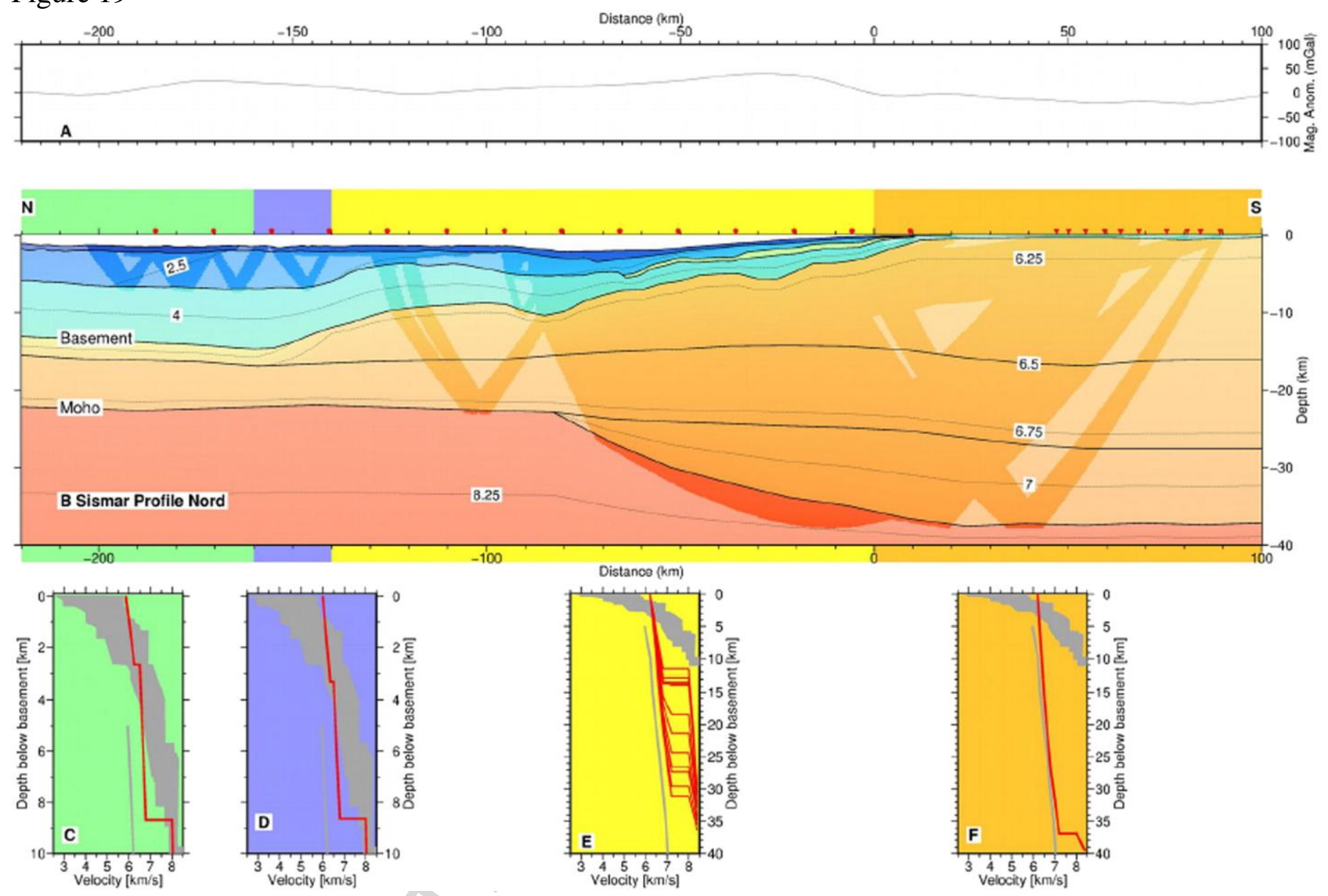
Figure 20
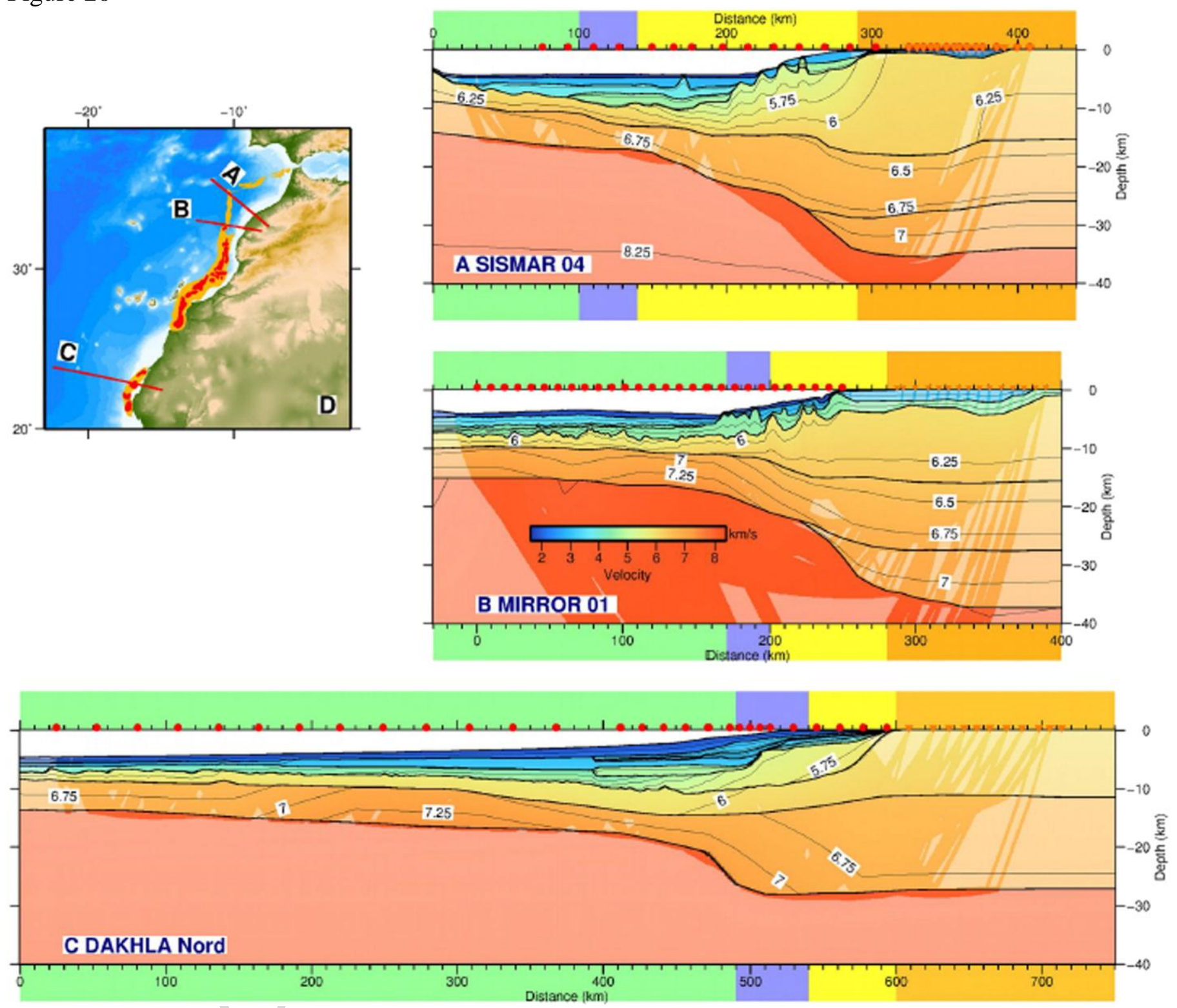
Figure 21
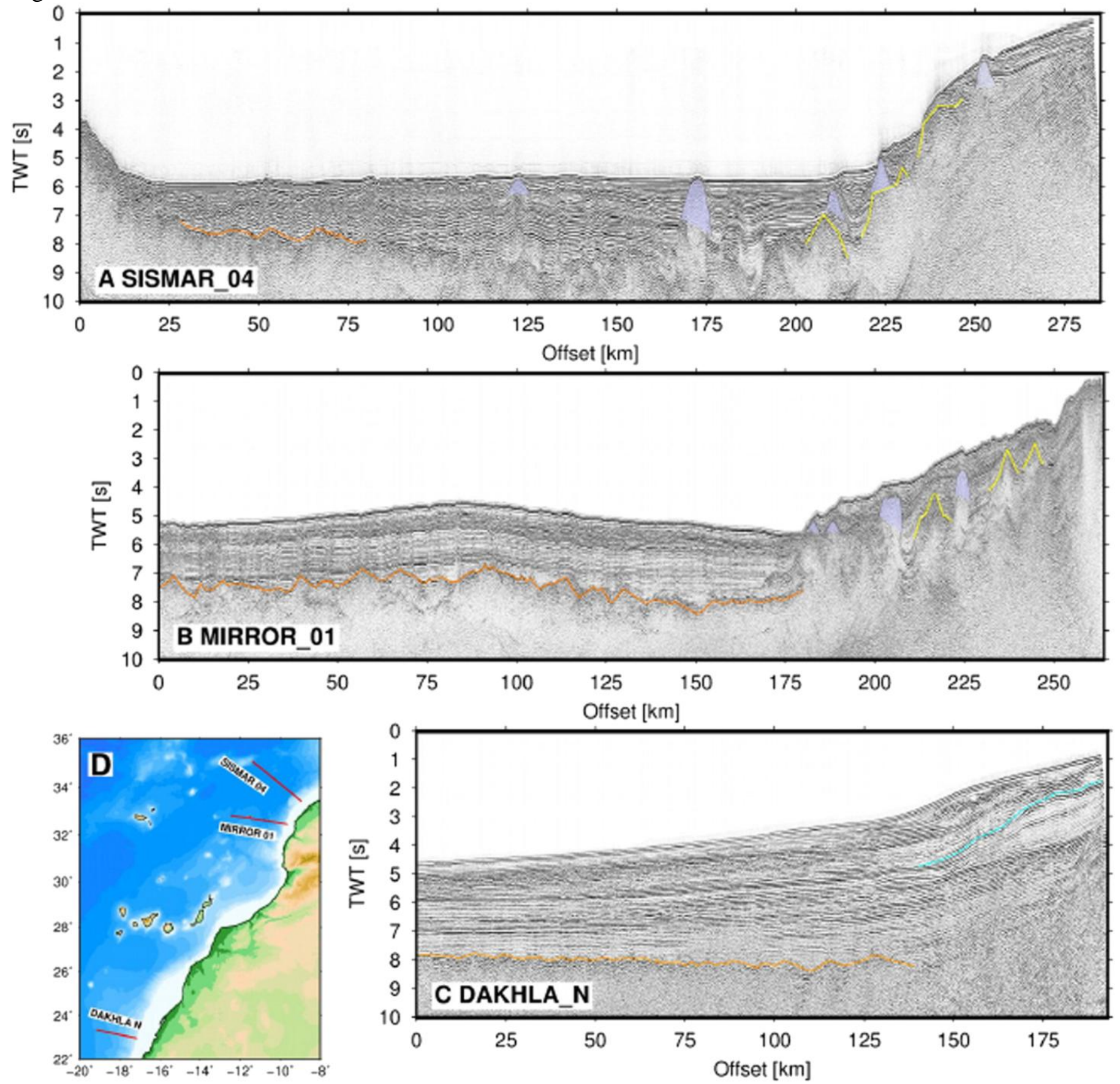
Figure 22

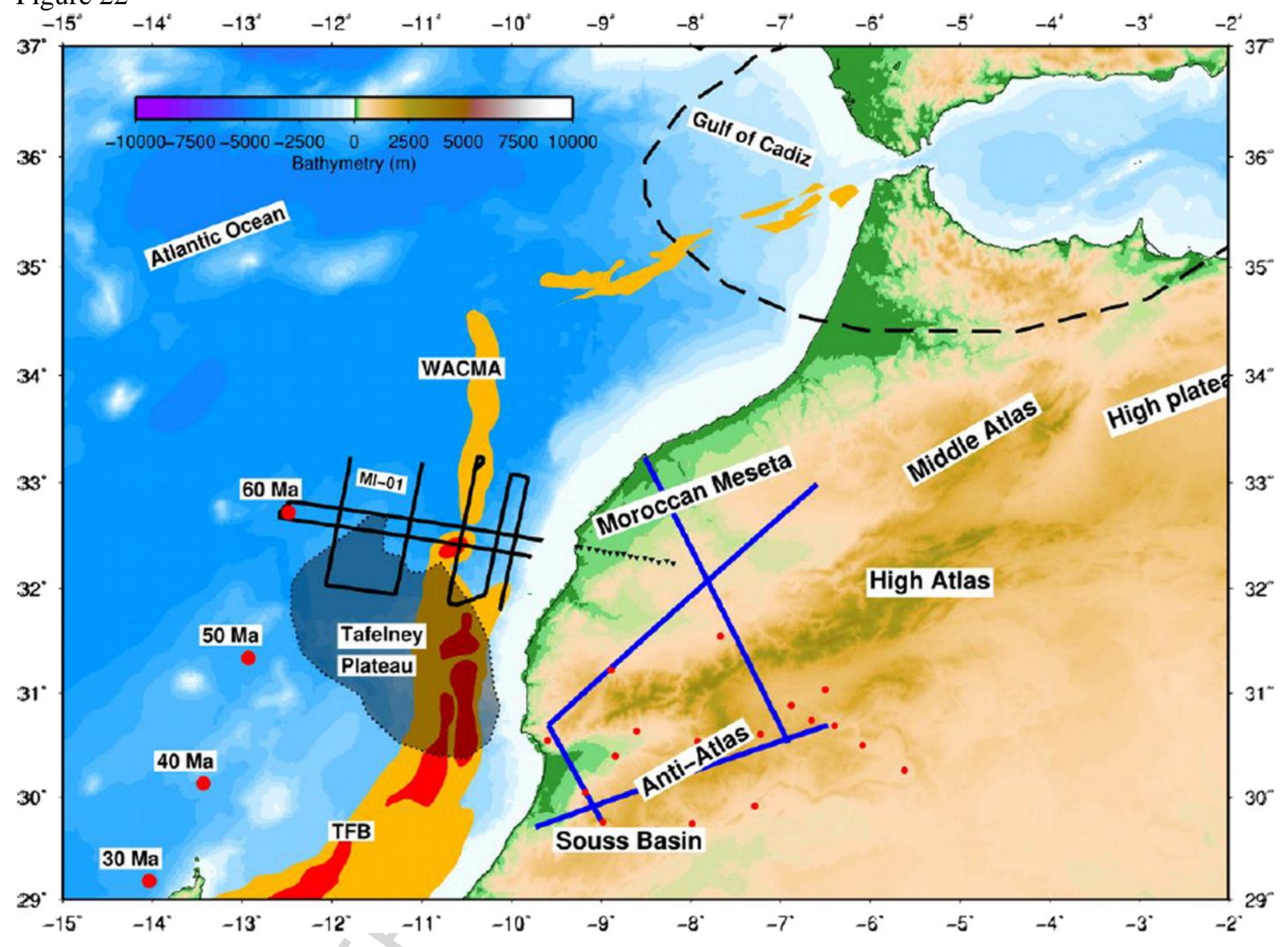


Figure 23

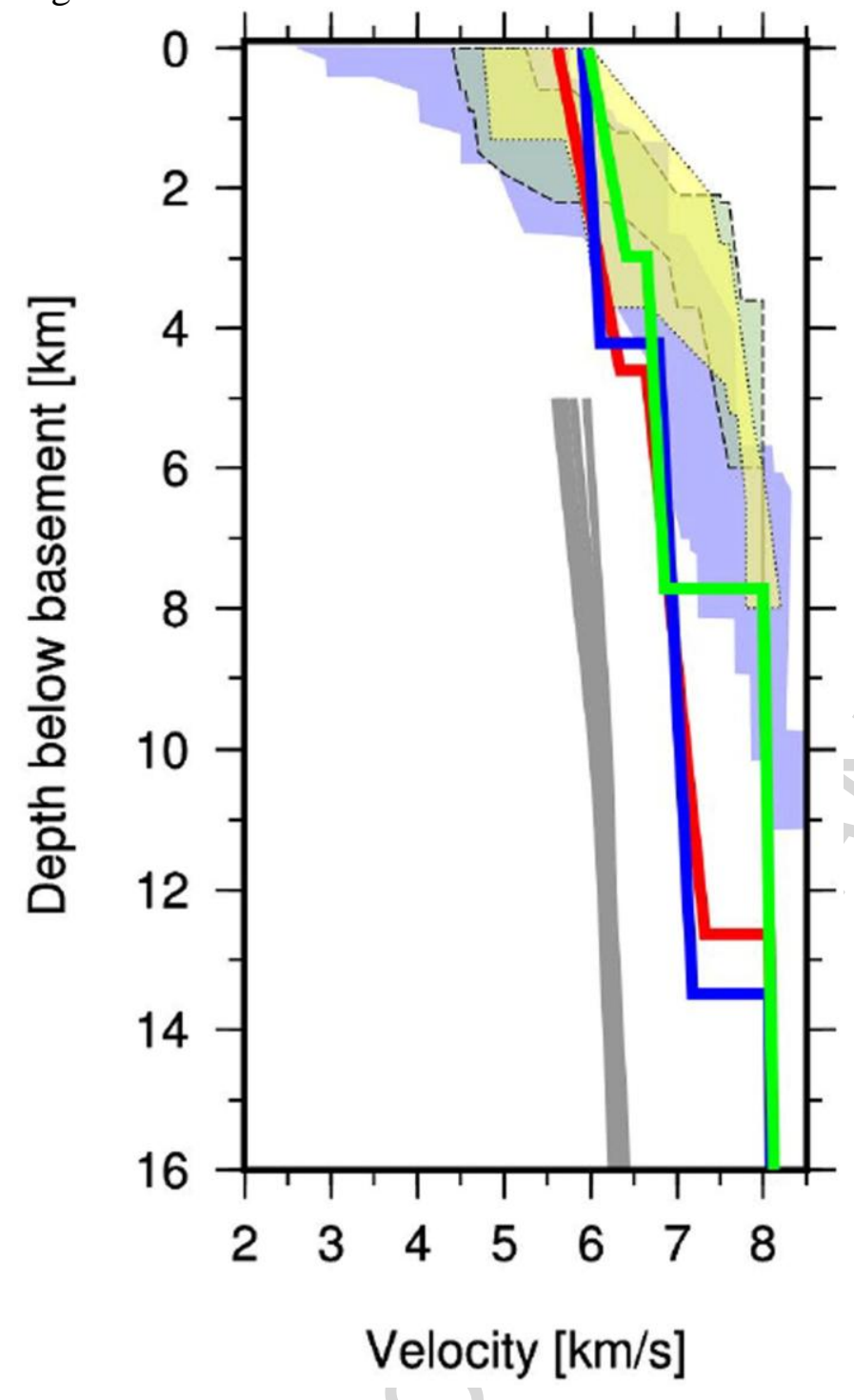


Figure 24

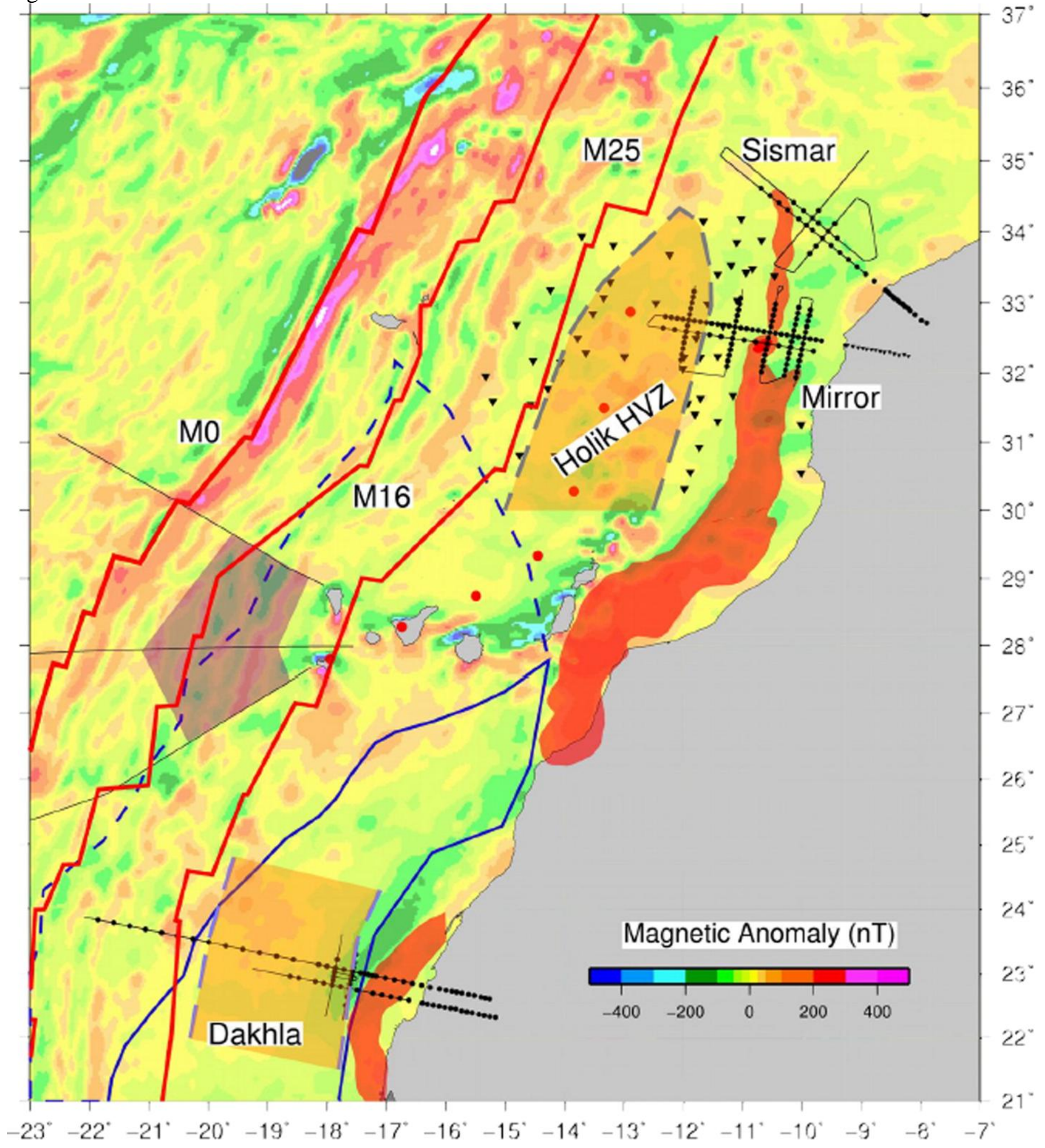


Figure 25
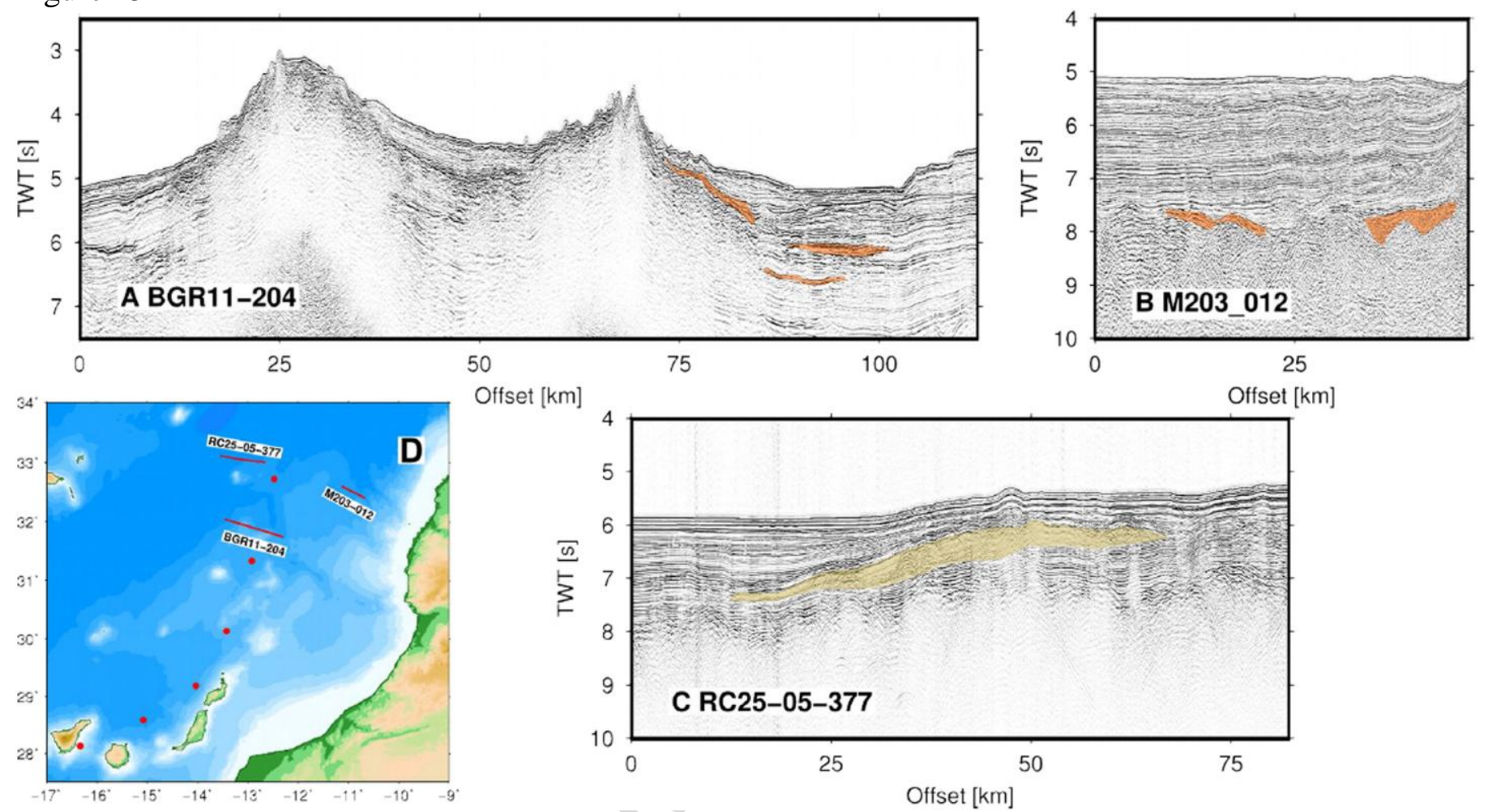

Offset [km]

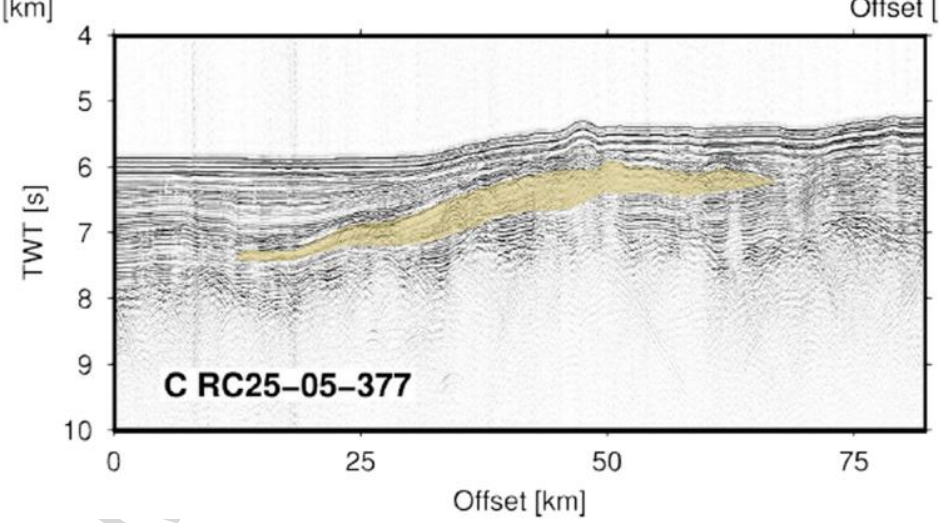


Figure 26

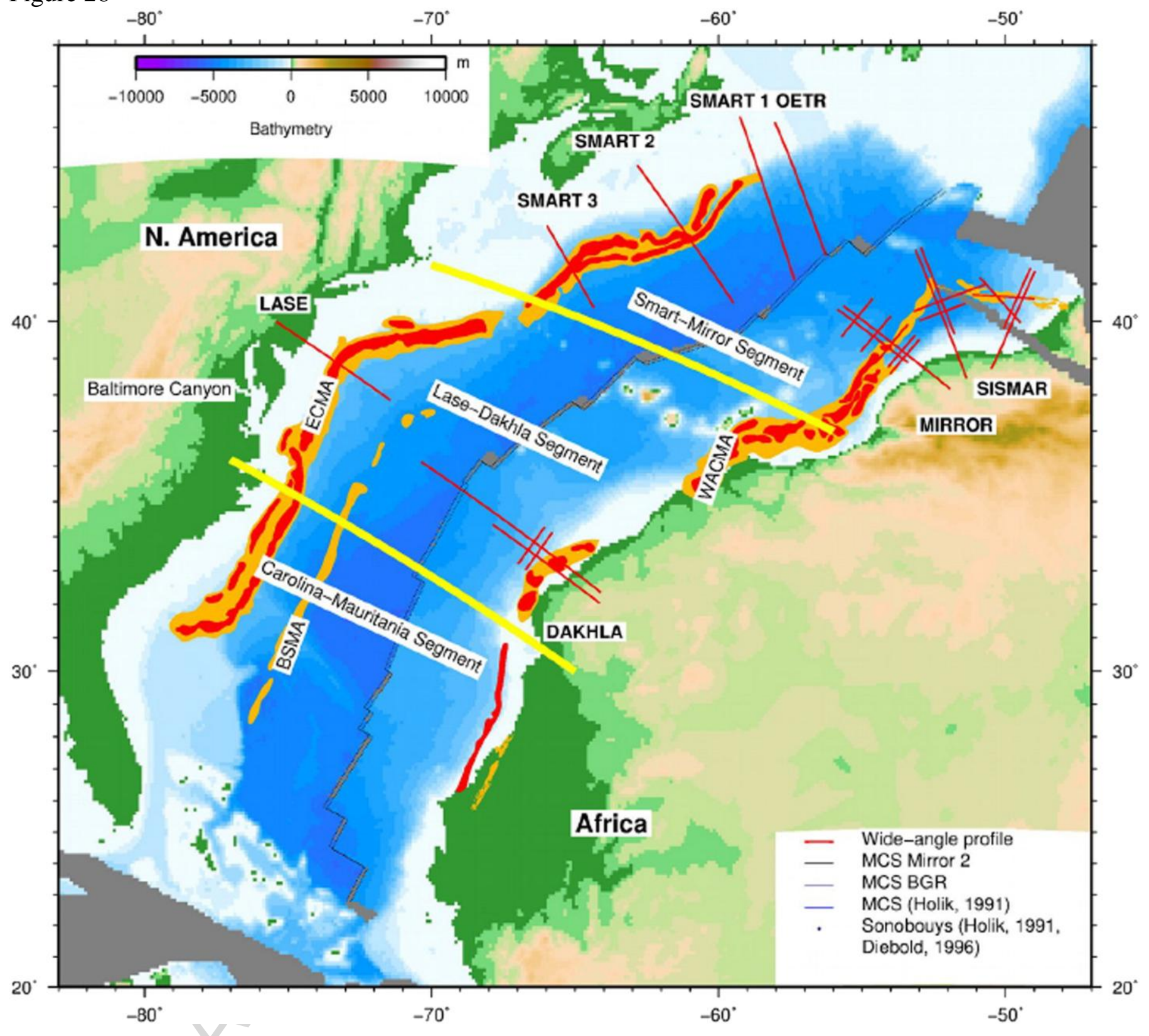


Figure 27

\section{Northern Moroccan Basin}

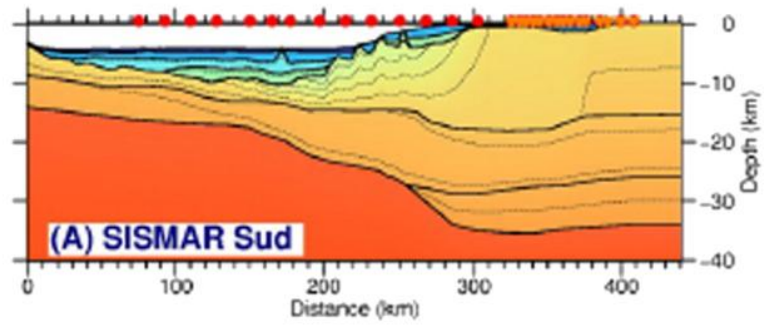

Segment Smart-Mirror
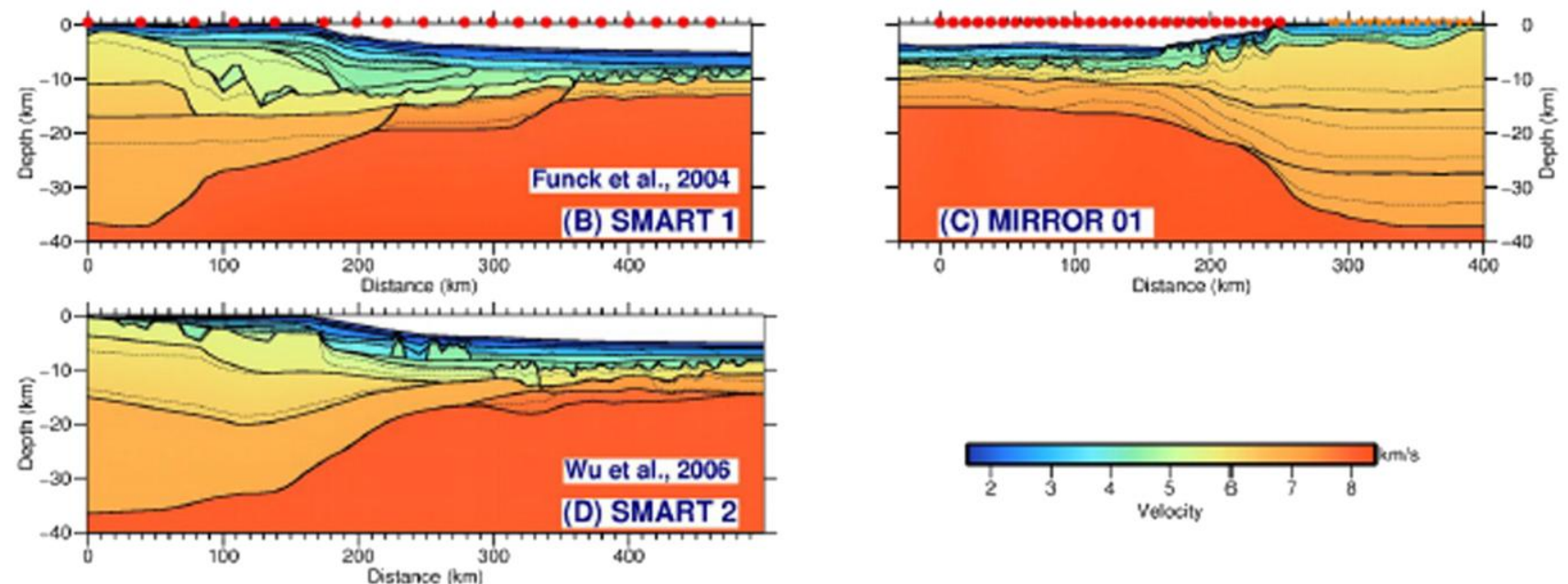

Segment Dakhla
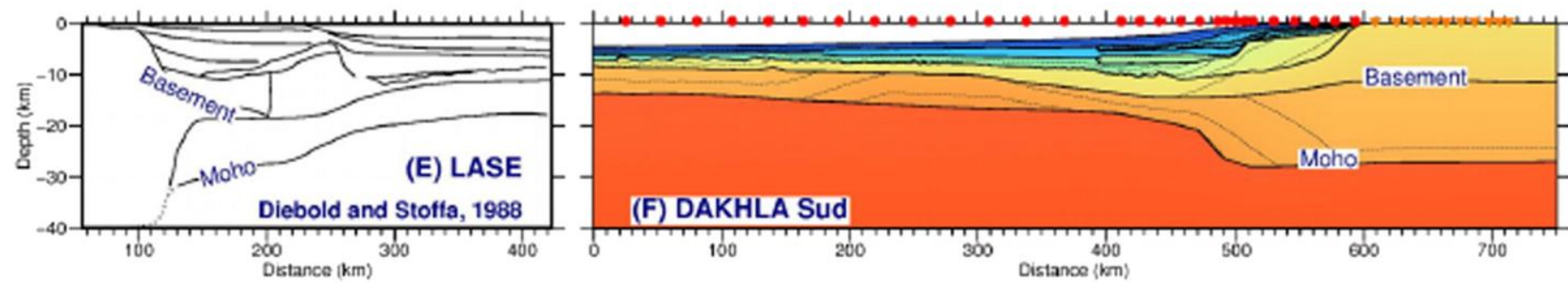
Figure 28
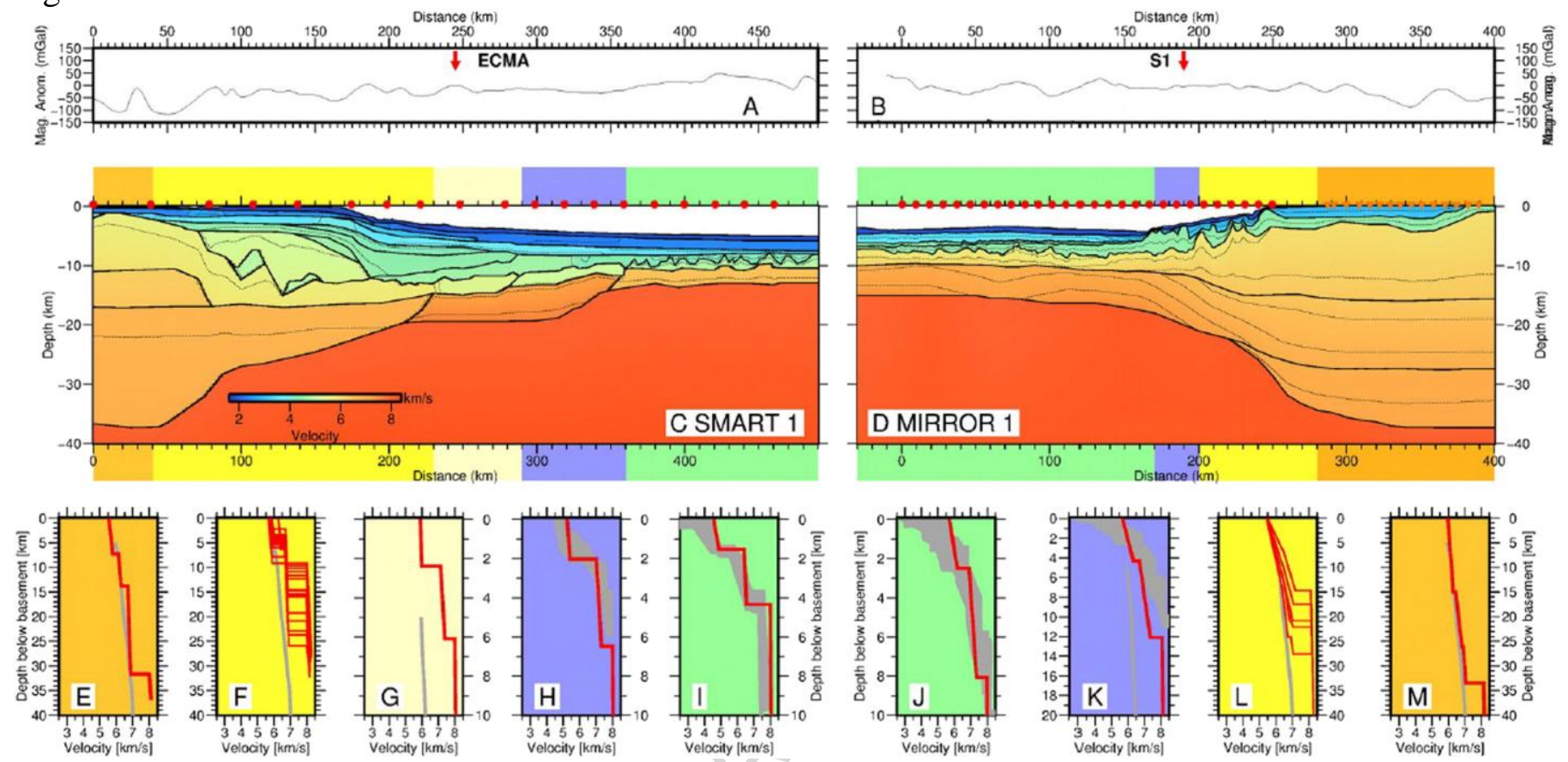
Figure 29

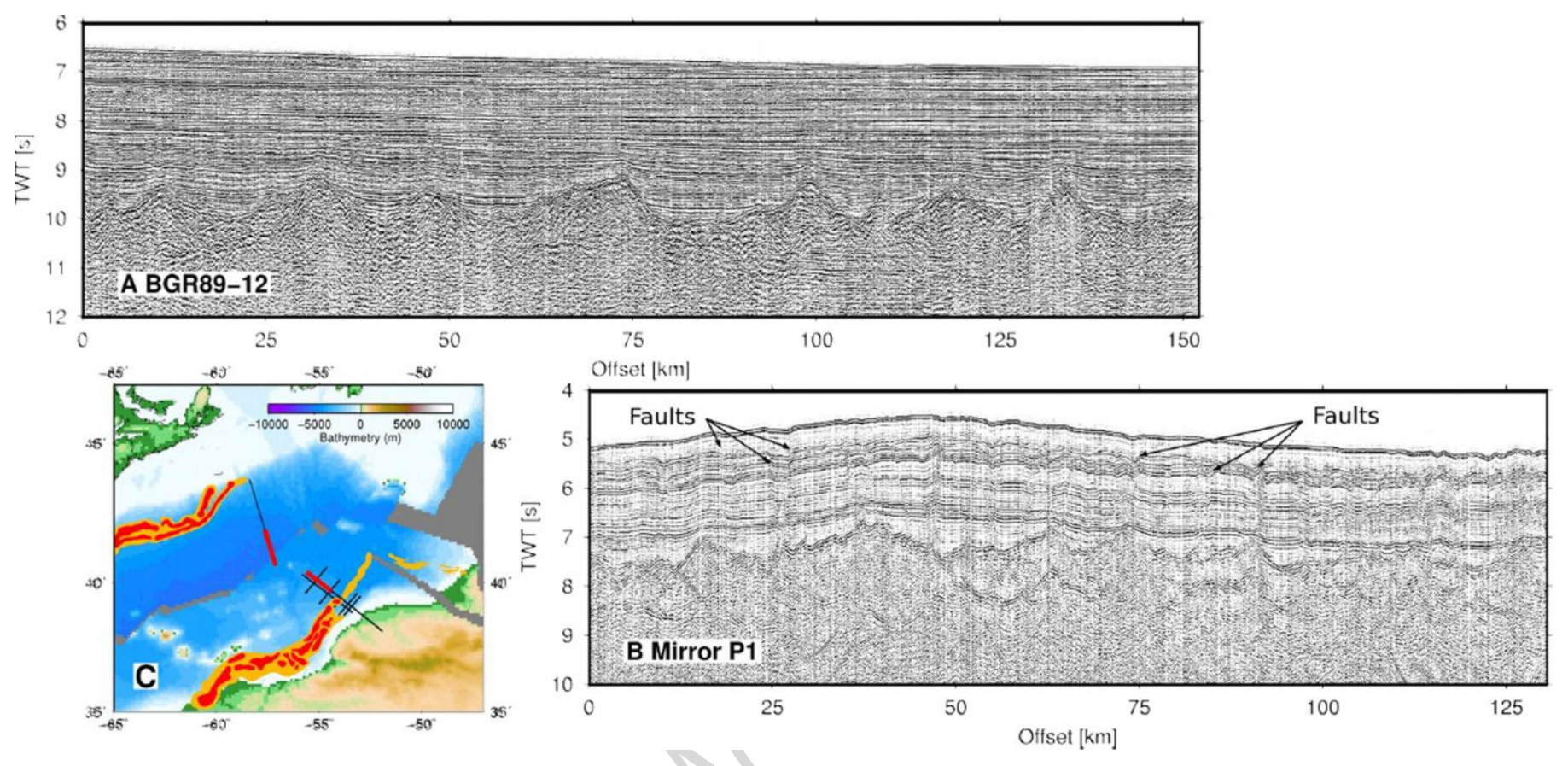

